\title{
Arctic Holocene proxy climate database - new approaches to assessing geochronological accuracy and encoding climate variables
}

\author{
H. S. Sundqvist ${ }^{1,2}$, D. S. Kaufman ${ }^{3}$, N. P. McKay ${ }^{3}$, N. L. Balascio ${ }^{4}$, J. P. Briner ${ }^{5}$, L. C. Cwynar ${ }^{6}$, H. P. Sejrup ${ }^{7}$, \\ H. Seppä ${ }^{8}$, D. A. Subetto ${ }^{9,10,11}$, J. T. Andrews ${ }^{12}$, Y. Axford ${ }^{13}$, J. Bakke ${ }^{7,14}$, H. J. B. Birks ${ }^{15,16,17}$, S. J. Brooks ${ }^{18}$, A. de \\ Vernal $^{19}$, A. E. Jennings ${ }^{12}$, F. C. Ljungqvist ${ }^{2,20}$, K. M. Rühland ${ }^{21}$, C. Saenger ${ }^{22}$, J. P. Smol ${ }^{21}$, and A. E. Viau ${ }^{23}$ \\ ${ }^{1}$ Department of Physical Geography \& Quaternary Geology, Stockholm University, Stockholm, Sweden \\ ${ }^{2}$ Bolin Centre for Climate Research, Stockholm University, Stockholm, Sweden \\ ${ }^{3}$ School of Earth Sciences \& Environmental Sustainability, Northern Arizona University, Flagstaff, USA \\ ${ }^{4}$ Lamont-Doherty Earth Observatory of Columbia University, Palisades, New York, USA \\ ${ }^{5}$ Department of Geology, University at Buffalo, New York, USA \\ ${ }^{6}$ Department of Biology, University of New Brunswick, Fredericton, Canada \\ ${ }^{7}$ Department of Earth Sciences, University of Bergen, Bergen, Norway \\ ${ }^{8}$ Department of Geosciences and Geography, University of Helsinki, Helsinki, Finland \\ ${ }^{9}$ Northern Water Problems Institute, Karelian Research Center, Russian Academy of Sciences, Petrozavodsk, Russia \\ ${ }^{10}$ Herzen State Pedagogical University of Russia, Saint Petersburg, Russia \\ ${ }^{11}$ Kazan Federal University, Kazan, Russia \\ ${ }^{12}$ Institute of Arctic and Alpine Research, University of Colorado, Boulder, USA \\ ${ }^{13}$ Department of Earth \& Planetary Sciences, Northwestern University, Illinois, USA \\ ${ }^{14}$ Bjerknes Centre for Climate Research, University of Bergen, Bergen, Norway \\ ${ }^{15}$ Department of Biology, University of Bergen, Bergen, Norway \\ ${ }^{16}$ Environmental Change Research Centre, University College London, UK \\ ${ }^{17}$ School of Geography and the Environment, University of Oxford, London, UK \\ ${ }^{18}$ Department of Life Sciences, Natural History Museum, London, UK \\ ${ }^{19}$ GEOTOP, Université du Québec à Montréal, Montreal, Canada \\ ${ }^{20}$ Department of History, Stockholm University, Stockholm, Sweden \\ ${ }^{21}$ Paleoecological Environmental Assessment and Research Lab (PEARL), Department of Biology, Queen's University, \\ Ontario, Canada \\ ${ }^{22}$ Joint Institute for the Study of the Atmosphere and Ocean, University of Washington, Seattle, USA \\ ${ }^{23}$ Department of Geography, University of Ottawa, Ottawa, Canada
}

Correspondence to: D. S. Kaufman (darrell.kaufman@nau.edu)

Received: 2 December 2013 - Published in Clim. Past Discuss.: 6 January 2014

Revised: 6 June 2014 - Accepted: 17 June 2014 - Published: 29 August 2014

\begin{abstract}
We present a systematic compilation of previously published Holocene proxy climate records from the Arctic. We identified 170 sites from north of $58^{\circ} \mathrm{N}$ latitude where proxy time series extend back at least to 6 cal ka (all ages in this article are in calendar years before present - BP), are resolved at submillennial scale (at least one value every $400 \pm 200$ years) and have age models constrained by at least one age every 3000 years. In addition to conventional meta-
\end{abstract}

data for each proxy record (location, proxy type, reference), we include two novel parameters that add functionality to the database. First, "climate interpretation" is a series of fields that logically describe the specific climate variable(s) represented by the proxy record. It encodes the proxy-climate relation reported by authors of the original studies into a structured format to facilitate comparison with climate model outputs. Second, "geochronology accuracy score" (chron score) 
is a numerical rating that reflects the overall accuracy of ${ }^{14} \mathrm{C}$ based age models from lake and marine sediments. Chron scores were calculated using the original author-reported ${ }^{14} \mathrm{C}$ ages, which are included in this database. The database contains 320 records (some sites include multiple records) from six regions covering the circumpolar Arctic: Fennoscandia is the most densely sampled region (31\% of the records), whereas only five records from the Russian Arctic met the criteria for inclusion. The database contains proxy records from lake sediment $(60 \%)$, marine sediment $(32 \%)$, glacier ice $(5 \%)$, and other sources. Most $(61 \%)$ reflect temperature (mainly summer warmth) and are primarily based on pollen, chironomid, or diatom assemblages. Many (15\%) reflect some aspect of hydroclimate as inferred from changes in stable isotopes, pollen and diatom assemblages, humification index in peat, and changes in equilibrium-line altitude of glaciers. This comprehensive database can be used in future studies to investigate the spatio-temporal pattern of Arctic Holocene climate changes and their causes. The Arctic Holocene data set is available from NOAA Paleoclimatology.

\section{Introduction}

Describing the spatio-temporal pattern of climate transitions provides insight into the relation between the mean climate state and dynamical aspects of climate change at the regional scale. This requires a large network of well-dated and well-resolved proxy climate records that captures the details of past climate variability. Such a synthesis of proxy climate time series can be used to assess the occurrence and strength of regional climate patterns and periodicities, and is needed for comparisons with the output of climate models. Databases that provide ready access to a large volume of information in a coherent, logical and flexible format will facilitate new research and accelerate discovery in climate science (Overpeck et al., 2011; Emile-Geay and Eshleman, 2013).

Previous Holocene palaeoclimate syntheses have emphasized time slices, especially of $6 \mathrm{ka}$ (all ages in this article are in calendar years before present - BP), and have relied heavily on pollen from terrestrial records (e.g. Bartlein et al., 2011), or have emphasized sea-surface temperatures from continental margins (Marcott et al., 2013). A relatively comprehensive database of available proxy data of all types has not yet been assembled into a unified format for effective analysis. Moreover, the geochronological data needed to quantify the uncertainty associated with the timing of palaeoclimate changes are rarely archived.

Building on previous Holocene palaeoclimate syntheses from the Arctic (CAPE, 2001; Bigelow et al., 2003; Kaufman et al., 2004; Sundqvist et al., 2010), we present a compilation of previously published proxy climate time series from north of $58^{\circ} \mathrm{N}$ latitude. All of the records extend back to at least $6 \mathrm{ka}$; nearly half of the sites $(44 \%)$ in the Holocene database extend to $10 \mathrm{ka}$, and $82 \%$ extend to at least $8 \mathrm{ka}$. We expand on previous work by including the entire time series of proxy data (rather than single time-slice values) and a wider array of proxy types, and by quantifying the temporal resolution of each record. Assessing the patterns of palaeoclimate change through space and time requires accurate chronological control, but the accuracy of the underlying geochronology varies among the proxy records. We therefore present a scheme for rating the geochronological accuracy of sediment-based proxies, the dominant source of Holocene proxy data in the Arctic. Comparing proxies to the output of earth system models also requires clear articulation of the climate variables represented by proxy records. We therefore present a scheme for characterizing the proxy climate variables. We also present the design of the database fields, the procedures and protocols used to populate the database, and we summarize its contents. Version 2.0 of the database is included with this paper; it is an update of version 1.0, which was published along with the earlier Discussion Paper (Sundqvist et al., 2014), and is available at NOAA Paleoclimatology 1 along with any future revisions.

\section{Procedures and protocols}

A vast assortment of unique Holocene proxy climate records is available from the Arctic. Developing a uniform database of proxy climate records requires a systematic approach to handle a data set based on such heterogeneous input. The database represents an extensive search of proxy climate records published prior to November 2013. A list of other Holocene palaeoclimate records that were considered but that did not meet the criteria for inclusion in this database is also included to document the scope of our search and to provide an annotated bibliography for future studies (Supplement Table S1). All proxy types were included from both terrestrial and marine environments, although we did not attempt a review of marine ice-rafted-debris records, which can have a complicated and variable relation to climate. Some proxy records have been calibrated using statistical procedures over the instrumental period to infer palaeoclimate change, assuming that the processes that control the proxy remain constant downcore (Tingley et al., 2012; von Storch et al., 2004). Other proxies rely on transfer functions based on the calibration of contemporary environmental gradients (Birks et al., 2010; Juggins and Birks, 2012), or the modern analogue technique (MAT), which uses the similarity between modern and fossil assemblages (e.g. Guiot and de Vernal, 2007). Unlike most proxy data compilations, we considered proxy records regardless of whether they were calibrated to a specific climate variable, provided that a peerreviewed study had demonstrated a clear relation between the

\footnotetext{
${ }^{1}$ http://ncdc.noaa.gov/paleo/study/15444.
} 
proxy and climate. Temperature-sensitive series from different proxy types can be combined to assess patterns of change spatially and temporally, regardless of the magnitude of the change (e.g. Fischer, 2002; Ljungqvist et al., 2012). For some sites, the database also includes the time series of properties from lake and marine sediment that were not interpreted in terms of a specific climate variable, but might give insight into other palaeoenvironmental changes.

The workload for generating a comprehensive data product was distributed among the co-authors of this study. The Arctic was subdivided into six regions (Fig. 1) and a representative from each region led a team of experts who conducted a comprehensive review of the literature, assessed the suitability of proxy records, identified the key proxy records from multiproxy studies, helped gather the numerical data, and checked the accuracy of the metadata and data. The six regions were delineated based loosely on the present-day spatial pattern of the Northern Annular Mode (Arctic Oscillation) as expressed by its correlation with summer temperature - the climate variable most frequently reconstructed by the proxies in the database. While regional representation brings expert knowledge to this project, the database comprises a coherent compilation of records from across the circumpolar Arctic that can easily be combined or subdivided to address specific research questions. The six regions (and their project leaders) are (1) Alaska and Yukon (D. S. Kaufman), (2) mainland Canada (L. C. Cwynar), (3) Canadian Arctic Archipelago and Greenland (J. P. Briner), (4) North Atlantic including Iceland (H. P. Sejrup), (5) Fennoscandia (H. Seppä), and (6) Arctic Russia (D. A. Subetto). In addition, to facilitate community-wide input, a call for participation was made at professional meetings (e.g. Kaufman, 2011), the project was announced on the Past Global Changes (PAGES) website, and an open-source outlet with a public discussion phase was chosen for the publication.

Age uncertainty in proxy time series is a fundamental limitation in reconstructions of past climate, especially for those aimed at assessing the synchronicity of change across a region. To address this, we developed a systematic, reproducible, and flexible scheme for judging the overall accuracy of ${ }^{14} \mathrm{C}$-based age models from sedimentary sequences and applied it to the database (Appendix A). This required the recovery and input of the original ${ }^{14} \mathrm{C}$ data for each of the sediment-based records. These data are critical for updating and standardizing age models, as well as calculating agemodel ensembles that will enable a statistical approach for quantifying uncertainty in the time domain.

\section{Selection criteria}

The criteria for the inclusion of an individual palaeoclimate record in the database are the following:

(i) Located at northern high latitudes. The database includes records from north of $58^{\circ} \mathrm{N}$. We recognize that

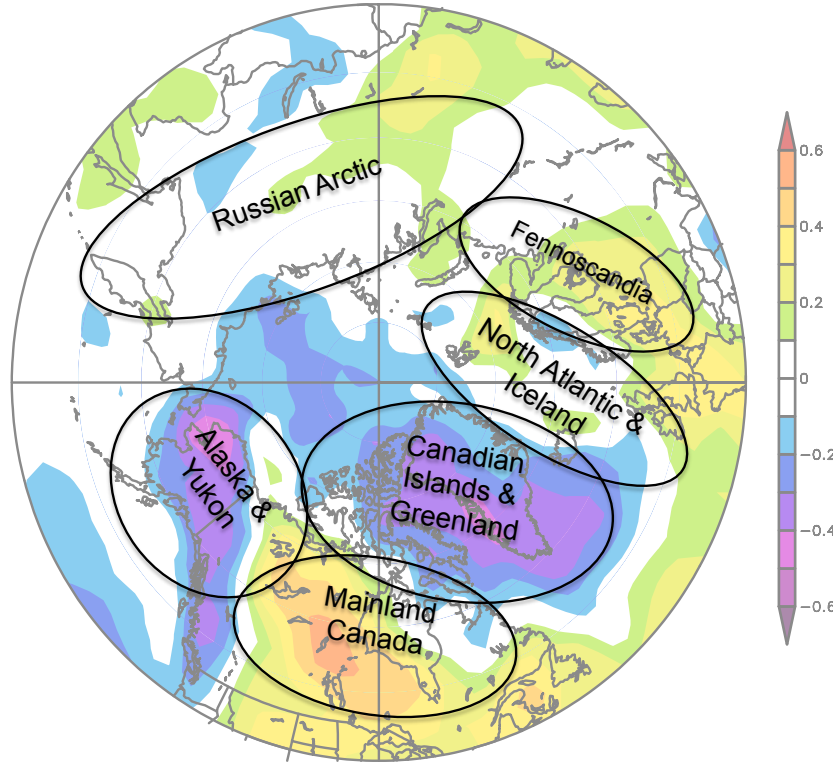

Figure 1. Six Arctic regions represented in this database. Map colours indicate strength of correlation between summer (JJA) surface air temperature and the Arctic Oscillation from 1950 to 2011 within the NCEP/NCAR Reanalysis data (output from NOAA/ESRL Physical Sciences Division).

this is only one of many approaches to delimiting the broadly defined Arctic region. We chose a latitudebased cutoff because it is easy to apply, and $58^{\circ} \mathrm{N}$ is far enough south to encompass nearly the entire subarctic zone. The database can be sorted by latitude to select the more strictly defined Arctic sites.

(ii) Demonstrated relation with a climate variable. The database includes proxy records of all types that have been used to quantify past changes in temperature, moisture, and other climate variables. In addition, to expand the coverage of the database, and recognizing that some research questions can be addressed by knowing the timing and direction of climate change, we also include proxy records that have not been transformed into quantitative estimates of climate variables, but that have been interpreted by the authors of the original study as relating to one or more climate variables.

(iii) Continuous time series that include (at minimum) the entire 6-2 ka period. Our interest is the entire postglacial period, but most proxy records do not extend through the Holocene. We excluded records that did not go back to at least $6 \mathrm{ka}$. Likewise, some records do not extend up to the present and we excluded those that did not extend to at least $2 \mathrm{ka}$. Our database complements and was developed in concert with the proxy database focused on the last 2000 years, which is overseen by the Past Global Changes (PAGES) Arctic2k Working 
Group. The Arctic2k data are archived by NOAA Paleoclimatology ${ }^{2}$.

(iv) Resolved at submillennial scale. The sample resolution of each record was calculated as the average time between data points for the period of common overlap for all records (6-2 ka), and two standard deviations of that average was used to quantify the regularity of the data spacing. We included records with an average sample resolution of at least 400 years and two standard deviations of less than \pm 200 years.

$R=\left(t_{n}-t_{1}\right) /(n-1)$,

where $R$ represents the sample resolution in years, $t_{1}$ the age of the first data point older than $2 \mathrm{ka}$ in the proxy time series, $t_{n}$ the age of the last data point younger than $6 \mathrm{ka}$, and $n$ the number of data points between 6 and $2 \mathrm{ka}$. This minimum resolution likely suffices for resolving submillennial patterns.

(v) Age constrained. We included records with age models constrained by at least one age every 3000 years back to $6 \mathrm{ka}$ (i.e. a minimum of 3000 years between ages). Sediment cores that lack a ${ }^{14} \mathrm{C}$ age younger than $3 \mathrm{ka}$ were rejected. This initial screening retains a high proportion of the available records $(\sim 60 \%)$, while recognizing that such coarse age control is insufficient to address questions that require centennial-scale accuracy. The age of the sediment core surface was included as an age-control point, provided that the sediment-water interface was preserved during sample collection.

(vi) Peer reviewed. All proxy records including palaeoclimate estimates in the database have been published in the peer-reviewed literature. The digital data for some sites were available through online data sources (67 out of 170), but the data from most of the sites were obtained directly from the authors of the original studies (103 out of 170) and are now being released as part of this data product. The limited number of records available through online archives underscores the usefulness of this database.

\section{Database structure and fields}

The database includes a single Excel (.xls) file containing the metadata for all sites (reproduced here as Table 1), and six Excel (.xls) files containing the primary proxy and geochronology data. Version 2.0 of the database is available as a Supplement to this article and at NOAA Paleoclimatology ${ }^{1}$. Any revisions will be posted at NOAA Paleoclimatology. The files are subdivided by region and each comprises sheets containing the primary data for each

\footnotetext{
${ }^{2} \mathrm{http} / / /$ ncdc.noaa.gov/paleo/study/16973.
}

site. In addition to these spreadsheet-based files, the database is configured in a self-describing and machine-readable format to interface with the Virtual Paleoclimate Laboratory in R (vplR; McKay et al., 2012). In this format, the data and metadata are structured in a flat text file that is easily read into structured arrays for data analysis or converted into alternative formats. In addition to the citations to the published records included in this database, we include a bibliography with citations to studies that were considered for inclusion in this database, but did not meet the specified criteria (Supplement Table S1).

\subsection{Proxy and geochronology data}

The proxy data for each site are listed in a separate sheet within each of the six regional files (Supplement). Each sheet contains the individual proxy records, including the depth and age of each of the samples used to develop the time series. The ages are from the published versions, except a few that were updated by calibrating ${ }^{14} \mathrm{C}$ ages to calendar age using the online version of Calib v5. Details about the sample thickness represented by each data point are included where they are available from the original publication, or when conveyed to us by their authors. This information is needed for precise determination of the smoothing effect of the sampling scheme. Each site-level sheet includes a table listing the individual ${ }^{14} \mathrm{C}$ ages used to develop the age model for lake and marine cores, and U-Th ages for speleothems. Any supplemental age control including short-lived isotopes and tephras are also noted. This information was used to calculate the "geochronology accuracy score" (Appendix A).

\subsection{Metadata}

The metadata file (Table 1) includes basic information about the records contained within the database, with one entry (row) for each site. Some sites include multiple proxy records and their metadata are consolidated into a single row using a logical punctuation scheme to separate individual inputs and to connote modifiers (Table 1, notes). The data fields contained within the metadata include site location, type of proxy information (archive and proxy type), length of the record (youngest and oldest record ages), and reference to the original publication(s). In addition to conventional metadata, we have included several parameters for each proxy record that add functionality to the database by providing key variables for filtering the data to identify those records that best address a particular research question. These are outlined below:

Resolution. The average sample resolution and regularity of that spacing (Eq. 1) are listed. If the site includes multiple proxy records, the best average resolution is entered.

Author-interpreted climate variable. This is a series of six fields describing the specific climate variable(s) represented by the proxy record. It encodes the proxy-climate relation as 
Table 1. Sites with proxy records in the database arranged by six Arctic regions. Some sites include more than one proxy record (see Table 2). (Notes: Site short name: title of tab in excel spreadsheet - database with proxy and geochronology data. Punctuation for proxy types connotes the following: $x . y-x$ : general type of analysis, and y: specific type of analysis or material (e.g. " $\mathrm{d}^{18} \mathrm{O}$.foram": oxygen-isotope of foraminifera); $\mathrm{x}, \mathrm{y}, \mathrm{z}$ - different proxy records from the same site. Proxy type abbreviations as follows: BSi: biogenic-silica content; DBD: dry bulk density; MAR: mass accumulation rate; MS: magnetic susceptibility; N, C, S: nitrogen, carbon, sulfur; OM: organic-matter content; TOC: total organic carbon. Oldest and youngest ages are in calendar years before AD 1950 (yr BP). Chron score: geochronology accuracy score calculated using the formulas and weighting factors in Appendix A and the " ${ }^{14} \mathrm{C}$ material" type listed in the adjacent column.)

\begin{tabular}{|c|c|c|c|c|c|c|c|c|c|c|c|c|c|}
\hline $\begin{array}{l}\text { Site } \\
\text { short name }\end{array}$ & Site & $\begin{array}{l}\text { General } \\
\text { location }\end{array}$ & $\begin{array}{l}\text { Lat } \\
\left({ }^{\circ}\right)\end{array}$ & $\begin{array}{r}\text { Long } \\
\left({ }^{\circ}\right)\end{array}$ & $\begin{array}{r}\begin{array}{r}\text { Elev } \\
(\mathrm{m})\end{array} \\
\end{array}$ & Source & Proxy & $\begin{array}{r}\text { Oldest } \\
\text { (yr BP) }\end{array}$ & $\begin{array}{r}\text { Youngest } \\
\text { (yr BP) }\end{array}$ & $\begin{array}{r}\text { Resolution } \\
(\mathrm{yr})\end{array}$ & $\begin{array}{r}{ }^{14} \mathrm{C} \\
\text { material }\end{array}$ & $\begin{array}{c}\text { Chron } \\
\text { score }\end{array}$ & Citation \\
\hline \multicolumn{14}{|c|}{ Alaska and Yukon } \\
\hline andy & Andy Lake & Northwest Territory & 64.65 & -128.08 & 1360 & lake & pollen & 13192 & 0 & 236 & 1 & -1.9 & $\begin{array}{l}\text { Viau and Gajewski (2009); } \\
\text { Szeicz et al. (1995) }\end{array}$ \\
\hline bells & Bell's Lake & Northwest Territory & 65.02 & -127.48 & 580 & lake & pollen & 13299 & 0 & 256 & 3 & -1.6 & $\begin{array}{l}\text { Viau and Gajewski (2009); } \\
\text { Szeicz et al. (1995) }\end{array}$ \\
\hline candelabra & $\begin{array}{l}\text { Candelabra } \\
\text { Lake }\end{array}$ & Yukon & 61.68 & -130.65 & 1040 & lake & pollen & 12567 & 352 & 222 & 2 & 0.0 & $\begin{array}{l}\text { Viau and Gajewski (2009); } \\
\text { Cwynar and Spear (1995) }\end{array}$ \\
\hline dune & Dune Lake & Interior Alaska & 64.42 & -149.90 & 134 & lake & $\mathrm{d}^{13} \mathrm{C}$.bulk & 11326 & -43 & 31 & 4 & 2.5 & Finney et al. (2012) \\
\hline farewell & Farewell Lake & Interior Alaska & 62.55 & -153.63 & 230 & lake & MgCa.ostracodes & 12517 & -50 & 242 & 3 & 0.9 & Hu et al. (1998) \\
\hline GGC19 & GGC-19 & Chukchi Sea & 72.16 & -155.51 & -369 & marine & $\begin{array}{l}\mathrm{d}^{18} \mathrm{O} \text {.forams, } \\
\text { dinocysts, dinocysts }\end{array}$ & 6660 & 52 & 76 & 4 & 4.4 & Farmer et al. (2011) \\
\hline greyling & Greyling Lake & S Alaska & 61.40 & -145.70 & 1015 & lake & OM & 18127 & -29 & 162 & 4 & 0.6 & Mckay and Kaufman (2009) \\
\hline $\begin{array}{l}\text { hail } \\
\text { halls }\end{array}$ & Hail Lake & Yukon & 60.03 & -129.02 & 690 & lake & pollen & 11334 & 67 & 136 & 4 & 1.2 & $\begin{array}{l}\text { Viau and Gajewski (2009); } \\
\text { Cwynar and Spear (1995) }\end{array}$ \\
\hline hallet & Hallet Lake & S Alaska & 61.50 & -146.20 & 1128 & lake & OM, BSi & 7913 & -52 & 35 & 4 & 4.6 & Mckay and Kaufman (2009) \\
\hline HLY0501 & HLY0501-05 & Chukchi Sea & 72.69 & -157.52 & -415 & marine & dinocysts & 8209 & 225 & 116 & 2 & 1.3 & $\begin{array}{l}\text { de Vernal et al. (2013); } \\
\text { McKay et al. (2008) }\end{array}$ \\
\hline honeymoon & $\begin{array}{l}\text { Honeymoon } \\
\text { Pond }\end{array}$ & Yukon & 64.63 & -138.40 & 1160 & lake & pollen & 10795 & 17 & 154 & 2 & -0.4 & $\begin{array}{l}\text { Viau and Gajewski (2009); } \\
\text { Cwynar and Spear (1991) }\end{array}$ \\
\hline hudson & Hudson Lake & S Alaska & 61.90 & -145.67 & 657 & lake & chironomids & 9574 & -28 & 117 & 4 & 3.3 & Clegg et al. (2011) \\
\hline jellybean & Jellybean Lake & Yukon & 60.35 & -134.80 & 730 & lake & $\mathrm{d}^{18} \mathrm{O}$.calcite & 7556 & -52 & 22 & 4 & 4.0 & Anderson et al. (2005) \\
\hline kusawa & Kusawa Lake & SW Yukon & 60.28 & -136.18 & 671 & lake & $\mathrm{BSi}$ & 12298 & 77 & 87 & 4 & 1.6 & Chakraborty et al. (2010) \\
\hline lily & $\begin{array}{l}\text { Lily Lake } \\
\text { f }\end{array}$ & Alaska & 59.20 & -135.40 & 230 & lake & pollen & 12740 & 54 & 208 & 1 & -1.3 & Cwynar (1990) \\
\hline logan & Mt Logan & Yukon & 60.58 & -140.50 & 5300 & ice & $\mathrm{d}^{18} \mathrm{O}$.ice & 12950 & -40 & 10 & $\mathrm{NA}$ & $\mathrm{NA}$ & Fisher et al. (2008) \\
\hline lonespruce & $\begin{array}{l}\text { Lone Spruce } \\
\text { Pond }\end{array}$ & SW Alaska & 60.01 & -159.14 & 135 & lake & $\mathrm{BSi}$ & 14524 & -5 & 40 & 4 & 3.4 & Kaufman et al. (2012) \\
\hline meleze & Lac Meleze & Northwest Territory & 65.22 & -126.12 & 650 & lake & pollen & 13699 & -32 & 299 & 1 & -3.1 & $\begin{array}{l}\text { Viau and Gajewski (2009); } \\
\text { MacDonald (1987) }\end{array}$ \\
\hline mica & Mica Lake & S Alaska & 60.95 & -148.15 & 3 & lake & $\mathrm{d}^{18}$ O.diatom & 9504 & -44 & 212 & 4 & 3.3 & Schiff et al. (2009) \\
\hline moose & Moose Lake & S Alaska & 61.37 & -143.60 & 437 & lake & chironomids & 6008 & -20 & 47 & 4 & 3.7 & Clegg et al. (2010) \\
\hline P1B3 & $\mathrm{P} 1 / \mathrm{B} 3$ & Chukchi Sea & 73.68 & -162.66 & -201 & marine & dinocysts & 9626 & 126 & 145 & 2 & 0.7 & de Vernal et al. (2005) \\
\hline quartz & Quartz Lake & Interior Alaska & 64.21 & -145.81 & 293 & lake & chironomids & 10949 & 777 & 212 & 3 & 1.5 & Wooller et al. (2012) \\
\hline rainbow & Rainbow Lake & S Alaska & 60.72 & -150.80 & 63 & lake & chironomids & 13506 & -54 & 301 & 4 & 2.6 & Clegg et al. (2011) \\
\hline ranger & Ranger Lake & Alaska & 67.15 & -153.65 & 820 & lake & pollen & 35525 & 0 & 369 & 1 & -1.1 & $\begin{array}{l}\text { Viau and Gajewski (2009); } \\
\text { Brubaker et al. (1983) }\end{array}$ \\
\hline screaminglynx & $\begin{array}{l}\text { Screaming Lynx } \\
\text { Lake }\end{array}$ & Alaska & 66.07 & -145.40 & 223 & lake & chironomids & 10611 & -43 & 72 & 4 & 2.3 & Clegg et al. (2011) \\
\hline takahula & Takahula Lake & Alaska & 67.35 & -153.67 & 275 & lake & $\mathrm{d}^{18}$ O.calcite & 8132 & -51 & 65 & 4 & 2.9 & Clegg and $\mathrm{Hu}(2010)$ \\
\hline trout & $\begin{array}{l}\text { Trout Lake - } \\
\text { combined }\end{array}$ & N Yukon & 68.83 & -138.75 & 150 & lake & chironomids & 15425 & 1784 & 207 & 3 & -0.6 & Irvine et al. (2012) \\
\hline upper_fly & $\begin{array}{l}\text { Upper Fly } \\
\text { Lake }\end{array}$ & S Yukon & 61.07 & -138.09 & 1326 & lake & pollen & 13417 & 0 & 206 & 4 & -0.3 & Bunbury and Gajewski (2009) \\
\hline waskey & Waskey Lake & SW Alaska & 59.88 & -159.21 & 150 & lake & DBD, OM & 10979 & 71 & 85 & 4 & 0.5 & Levy et al. (2004) \\
\hline wolverine & $\begin{array}{l}\text { Wolverine Lake } \\
\text { - April Core }\end{array}$ & N Alaska & 67.10 & -158.91 & & lake & MAR & 7407 & 24 & 33 & 4 & 0.4 & Mann et al. (2002) \\
\hline \multicolumn{14}{|c|}{ Canadian islands and Greenland } \\
\hline agassiz & Agassiz & Greenland & 80.70 & -73.10 & 1730 & ice & $\mathrm{d}^{18}$ O.ice, ice.melt & 11640 & 0 & 20 & NA & NA & Vinther et al. (2009) \\
\hline akvaquak & Akvaquak Lake & Baffin Island & 66.78 & -63.95 & 17 & lake & pollen & 8334 & 10 & 194 & 3 & 0.1 & Frechétte and de Vernal (2009) \\
\hline ARC3 & ARC-3 & Barrow Strait & 74.27 & -91.11 & -347 & marine & IP25 & 10021 & 439 & 16 & 2 & 0.3 & $\begin{array}{l}\text { Vare (2009); } \\
\text { Belt et al. (2010) }\end{array}$ \\
\hline $\mathrm{BC} 01$ & $\mathrm{BC} 01$ & Melville Peninsula & 75.18 & -111.92 & & lake & OM, MS, BSi & 12943 & -66 & 61 & 3 & -2.1 & Peros et al. (2010) \\
\hline big_round & Big Round Lake & Baffin Island & 69.87 & -68.86 & & lake & MS & 10186 & -56 & 16 & 4 & 2.9 & Thomas et al. (2010) \\
\hline braya_so & Braya $S_{\emptyset}$ & Kangerlussuaq & 67.00 & -50.70 & 170 & lake & alkenones & 6119 & -55 & 44 & 2 & 1.5 & D'andrea et al. (2011) \\
\hline century & Camp Century & Greenland & 77.17 & -61.13 & 1890 & ice & $\mathrm{d}^{18}$ O.ice & 11650 & -10 & 20 & $\mathrm{NA}$ & NA & Vinther et al. (2009) \\
\hline DA05 & DA05 & Kangersuneq fjord & 68.72 & -51.11 & -335 & marine & forams & 6883 & 1063 & 88 & 4 & 3.2 & Lloyd (2007) \\
\hline devon & Devon Ice Cap & Nunavut & 75.32 & -82.50 & & ice & $\mathrm{d}^{18} \mathrm{O}$.ice & 20539 & 39 & 50 & $\mathrm{NA}$ & $\mathrm{NA}$ & $\begin{array}{l}\text { Fisher et al. (1983, } \\
\text { updated by author) }\end{array}$ \\
\hline Dye3 & Dye-3 & Greenland & 65.18 & -43.82 & & ice & $\mathrm{d}^{18} \mathrm{O}$.ice & 11640 & -20 & 20 & $\mathrm{NA}$ & $\mathrm{NA}$ & Vinther et al. (2006) \\
\hline flower_valley & $\begin{array}{l}\text { Flower Valley } \\
\text { Lake }\end{array}$ & $\mathrm{S}$ Greenland & 65.61 & -37.69 & 73 & lake & $\mathrm{dD}$ & 8560 & 308 & 359 & 4 & 3.2 & Balascio et al. (2013) \\
\hline GISP2 & GISP2 & Greenland & 72.58 & -38.46 & 3216 & ice & $d^{18}$ O.ice & 49981 & 95 & 31 & $\mathrm{NA}$ & NA & Alley (2000) \\
\hline GRIP & GRIP & Greenland & 72.01 & -37.63 & 3230 & ice & $\mathrm{d}^{18} \mathrm{O}$.ice & 32380 & -20 & 20 & NA & $\mathrm{NA}$ & Vinther et al. (2006) \\
\hline hjort & Hjort Lake & Store Koldewey & 76.43 & -18.77 & 114 & lake & chironomids & 9773 & 488 & 300 & 3 & -0.8 & Schmidt et al. (2011) \\
\hline HU84 & HU84-030-021 & SW of Greenland & 58.37 & -57.51 & -2853 & marine & dinocysts & 8297 & 1968 & 158 & 4 & -2.5 & de Vernal et al. $(2001,2013)$ \\
\hline HU90 & HU90-013-017 & SW of Greenland & 58.21 & -48.37 & -3380 & marine & $\begin{array}{l}\text { dinocysts } \\
\text { ding }\end{array}$ & 11919 & 1362 & 132 & 4 & 1.1 & de Vernal et al. (2013) \\
\hline HU91 & $\begin{array}{l}\text { HU91-039-008 } \\
\text { PC }\end{array}$ & Baffin Bay & 77.27 & -74.33 & -663 & marine & dinocysts & 6756 & 1549 & 130 & 3 & 2.0 & $\begin{array}{l}\text { Levac et al. (2001); } \\
\text { de Vernal et al. (2013) }\end{array}$ \\
\hline igaliku & Igaliku Lake & Southern Greenland & 61.00 & -45.43 & 30 & lake & pollen.flux & 9527 & -51 & 117 & 4 & 3.2 & Massa et al. (2012) \\
\hline iglutalik & Iglutalk Lake & Nunavut & 66.14 & -66.08 & 90 & lake & pollen & 10269 & -24 & 177 & 1 & -2.0 & $\begin{array}{l}\text { Kerwin et al. (2004); } \\
\text { Davis (1980) }\end{array}$ \\
\hline jake & Jake Lake & Nunavut & 63.67 & -65.15 & 300 & lake & pollen & 8082 & -41 & 312 & 2 & -1.2 & $\begin{array}{l}\text { Kerwin et al. (2004); } \\
\text { Miller et al. (2005); }\end{array}$ \\
\hline LS009 & 2004-804-009 & Lancaster Sound & 74.19 & -81.20 & -781 & marine & dinocysts & 10821 & 2035 & 157 & $\mathrm{NA}$ & NA & $\begin{array}{l}\text { Ledu et al. (2010); } \\
\text { de Vernal et al. (2013) }\end{array}$ \\
\hline MD99-2227 & MD99-2227 & SW of Greenland & 58.21 & -48.37 & -3460 & marine & dinocysts & 11832 & 753 & 129 & 4 & 3.7 & $\begin{array}{l}\text { de Vernal and } \\
\text { Hillaire-Marcel (2006); } \\
\text { de Vernal et al. (2013) }\end{array}$ \\
\hline $\mathrm{N} 14$ & N14 & S Greenland & 59.98 & -44.18 & 101 & lake & $\mathrm{BSi}$ & 14377 & 320 & 22 & 3 & 2.2 & Andresen et al. (2004) \\
\hline naujg1 & NAUJG1-1 & W Greenland & 66.67 & -51.97 & 300 & lake & mineral.content & 9498 & 429 & 13 & 4 & 0.9 & Willemse and Törnqvist (1999) \\
\hline NGRIP & NGRIP & Greenland & 75.10 & -42.32 & 2917 & ice & $\mathrm{d}^{18} \mathrm{O}$.ice & 41700 & -40 & 20 & NA & NA & $\begin{array}{l}\text { Vinther et al. (2006); } \\
\text { NorthGRIP members (2004) }\end{array}$ \\
\hline north & North Lake & W Greenland & 69.24 & -50.03 & 190 & lake & $\begin{array}{l}\text { OM, BSi, } \\
\text { chironomids }\end{array}$ & 7271 & -52 & 72 & 4 & 4.1 & Axford et al. (2013) \\
\hline penny & Penny Ice Cap & Baffin Island & 67.25 & -66.75 & 1900 & ice & $\mathrm{d}^{18} \mathrm{O}$.ice & 11787 & -33 & 10 & NA & $\mathrm{NA}$ & Fisher et al. (1998) \\
\hline qipisirargo & Qipisarqo Lake & $\mathrm{S}$ Greenland & 61.00 & -47.75 & 7 & lake & pollen, BSi & 8634 & 8 & 176 & 2 & 0.5 & $\begin{array}{l}\text { Frechétte and de Vernal (2009); } \\
\text { Kaplan et al. (2002) }\end{array}$ \\
\hline
\end{tabular}


Table 1. Continued.

\begin{tabular}{|c|c|c|c|}
\hline renland & Renland & Greenland & 71.30 \\
\hline sfl4-1 & SFL-1 & W Greenland & 67.08 \\
\hline $\mathrm{SP} 02$ & $\mathrm{SP} 02$ & Melville Peninsula & 68.55 \\
\hline SS1381 & SS1381 & W Greenland & 67.01 \\
\hline SS16 & SS16 & W Greenland & 66.91 \\
\hline SS49 & SS49 & W Greenland & 66.86 \\
\hline SS8 & SS8 & W Greenland & 67.01 \\
\hline Fennoscandia & & & \\
\hline arapisto & Arapisto & S Finland & 60.58 \\
\hline austerkjosen & Austerkjosen & Nordland & 68.53 \\
\hline berkut & Berkut & Kola Peninsula & 66.35 \\
\hline bjornfjelltjorn & Bjørnfjelltjørn & N Norway & 68.43 \\
\hline brurskardstjorni & Brurskardstjørni & S Norway & 61.42 \\
\hline chuna & Chuna Lake & Kola Peninsula & 67.95 \\
\hline dalene & Dalene & S Norway & 58.25 \\
\hline dalmutladdo & Dalmutladdo & N Norway & 69.17 \\
\hline dravladalsvatn & Dravladalsvatn & Folgefonna & 60.03 \\
\hline fauske & Fauske & N Norway & 67.22 \\
\hline fiskebolvatnet & Fiskebølvatnet & NW Norway & 68.41 \\
\hline flarken & Flarken & C Sweden & 58.55 \\
\hline flotatjonn & Flotatjønn & S Norway & 59.67 \\
\hline gammelheimvatnet & Gammelheimvatnet & N Norway & 68.47 \\
\hline gilltjarnen & Gilltjärnen & C Sweden & 60.08 \\
\hline gloppsjon & Lilla Gloppsjön & C Sweden & 59.83 \\
\hline grostjorn & Grostjørna & S Norway & 58.53 \\
\hline gunnarsfjorden & Over Gunnarsfjorden & N Norway & 71.04 \\
\hline haugtjern & Haugtjern & S Norway & 60.83 \\
\hline holebudalen & Holebudalen & S Norway & 59.83 \\
\hline igelsjon & Igelsjön & C Sweden & 58.47 \\
\hline isbenttjonn & Isbenttjønn & S Norway & 59.77 \\
\hline jarburvatnet & Jarburvatnet & SW Norway & 61.70 \\
\hline kinnshaugen & Kinnshaugen & S Norway & 62.02 \\
\hline kjennsvatn & Austre Kjennsvatnet & N Norway & 66.00 \\
\hline klotjarnen & Klotjärnen & C Sweden & 61.82 \\
\hline kortlanda & Kortlandamossen 1 & C Sweden & 59.85 \\
\hline KP2 & $\mathrm{KP}-2$ & Kola Peninsula & 68.80 \\
\hline laihalampi & Laihalampi & S Finland & 61.48 \\
\hline lake850 & 850 & N Sweden & 68.37 \\
\hline lapland & lapland & Lapland & 69.00 \\
\hline liltlvatn & Litlvatnet & N Norway & 68.52 \\
\hline myrvatn & Myrvatnet & N Norway & 68.65 \\
\hline nattmalsvatn & Nattmålsvatn & SE Norway & 69.18 \\
\hline nautajarvi & Nautajärvi & S Finland & 61.80 \\
\hline nerfloen & Nerfloen & W Norway & 61.93 \\
\hline njakajaure & Voulep Njakajaure & N Sweden & 68.33 \\
\hline njulla & Njulla & $\mathrm{N}$ Sweden & 68.37 \\
\hline oykjamyrtjorn & Vestre Økjamyrttjørn & SW Norway & 59.82 \\
\hline raigastvere & Raigastvere & Estonia & 58.58 \\
\hline ratasjoen & Rảtasjøen & S Norway & 62.27 \\
\hline reiarsdalsvatnet & Reiarsdalvatnet & S Norway & 58.32 \\
\hline $\begin{array}{l}\text { ruila } \\
\text { naster }\end{array}$ & Ruila & Estonia & 59.17 \\
\hline rystad & Rystad 1 & N Norway & 68.24 \\
\hline saarikko & Saarikko & E Finland & 62.25 \\
\hline sellevollmyra & Sellevollmyra & N Norway & 69.11 \\
\hline sjuuodjijaure & Sjuodjijaure & N Sweden & 67.37 \\
\hline soylegrotta & Søylegrotta & N Norway & 66.62 \\
\hline spaime & Spåime & C Sweden & 63.12 \\
\hline stomyren & Stömyren & C Sweden & 60.21 \\
\hline $\begin{array}{l}\text { svanavatnet } \\
\text { suts }\end{array}$ & Svanăvatnet & N Norway & 66.44 \\
\hline svartkalstjarn & Svartkälstjärn & NE Sweden & 64.27 \\
\hline svartvatnet & Svartvatnet & S Norway & 63.35 \\
\hline tiavatnet & Tiåvatnet & S Norway & 63.05 \\
\hline tibetanus & Tibetanus & N Sweden & 68.33 \\
\hline tornetrask & Torneträsk & N Sweden & 68.00 \\
\hline toskaljavri & Toskaljavri & N Finland & 69.20 \\
\hline trehorningen & Trehörningen & C Sweden & 58.55 \\
\hline trettetjorn & Trettetjørn & SW Norway & 60.72 \\
\hline tsuolbmajavri & Tsuolbmajavri & N Finland & 68.41 \\
\hline vikjordvatnet & Vikjordavatnet & NW Norway & 68.23 \\
\hline vuoskkujavri & Vuoskkujavri & N Sweden & 68.33 \\
\hline yarnyshnoe & Yarnishnoe & Kola Peninsula & 69.07 \\
\hline Mainland Canada & & & \\
\hline $2005-804$ & 2005-804-006 & Victoria Strait & 68.99 \\
\hline ARC4 & ARC-4 & Victoria Strait & 69.17 \\
\hline ARC5 & ARC-5 & Dease Strait & 68.99 \\
\hline ennadai & Ennadai Lake & Nunavut & 61.17 \\
\hline JR01 & JR01 & Boothia Peninsula & 69.90 \\
\hline $\mathrm{k} 2$ & Lake K2 & N Québec & 58.73 \\
\hline KR02 & KR02 & Victoria Island & 71.34 \\
\hline LR01 & LR01 & E Hudson Bay & 58.58 \\
\hline $\mathrm{s} 53 \mathrm{~s} 52$ & $\mathrm{~S} 52 / \mathrm{S} 53$ & Saskatchewan & 59.89 \\
\hline toronto & Toronto Lake & C Canada & 63.72 \\
\hline unit & Unit Lake & W Hudson Bay & 59.40 \\
\hline whatever & Whatever Lake & C Canada & 64.68 \\
\hline North Atlantic an & eland & & \\
\hline B997-321 & B997-321 & W Iceland & 66.53 \\
\hline GIK23258 & GIK23258-2/3 & Norwegian Sea & 75.00 \\
\hline haukdalsvatn & Haukdalsvatn & Iceland & 65.03 \\
\hline hvitarvatn & Hvitarvatn & Iceland & 64.62 \\
\hline JM01-1199 & T88-2. JM01-1199 & Norwegian Sea & 71.99 \\
\hline JM96-1207 & JM96-1207 & Denmark Strait & 68.10 \\
\hline JR51-GC35 & JR51-GC35 & North of Iceland & 67.59 \\
\hline LO09 & LO09-14 & Reykjanes Ridge & 58.94 \\
\hline malangen & Malangenfjord & N Norway & 69.50 \\
\hline MD95-2011 & $\begin{array}{l}\text { MD95-2011, } \\
\text { JM997-948/2A BC }\end{array}$ & Norwegian Sea & 66.97 \\
\hline
\end{tabular}


Table 1. Continued.

\begin{tabular}{|c|c|c|c|c|c|c|c|c|c|c|c|c|c|}
\hline MD95-2015 & MD95-2015 & Northeast Atlantic & 58.77 & -25.97 & & marine & alkenones & 10028 & 725 & 83 & 4 & 2.6 & Giraudeau et al. (2000); Marchal et al. (2002) \\
\hline MD99-2256 & MD99-2256 & SW Iceland & 64.30 & -24.21 & 246 & marine & forams & 11333 & -43 & 91 & 2 & 1.4 & Ólafsdóttir et al. (2010) \\
\hline MD99-2264 & MD99-2264 & NW Iceland & 66.68 & -24.20 & 235 & marine & forams & 11503 & -24 & 67 & 2 & -0.5 & Ólafsdóttir et al. (2010) \\
\hline MD99-2269 & MD99-2269 & Denmark Strait & 66.85 & -20.85 & & marine & diatoms & 11477 & -16 & 37 & 4 & 4.2 & Justwan et al. (2008) \\
\hline MD99-2317 & MD99-2317 & SE Greenland Shelf & 68.10 & -27.86 & & marine & $\mathrm{d}^{18} \mathrm{O}$.foram, IRD & 13305 & 1013 & 25 & 4 & 1.9 & Jennings et al. (2011) \\
\hline MD99-2322 & MD99-2322 & SE Greenland Shelf & 67.14 & -30.83 & & marine & $\mathrm{d}^{18} \mathrm{O}$.foram, IRD, carbonate & 11776 & 197 & 20 & 4 & 3.1 & Jennings et al. (2011) \\
\hline mjauvotn & Mjáuvötn & Faroe Islands & 62.12 & -7.00 & 200 & lake & XRF, $\mathrm{d}^{13} \mathrm{C}, \mathrm{TOC}, \mathrm{N}, \mathrm{C}, \mathrm{S}, \mathrm{MS}$ & 11611 & -40 & 13 & 4 & 2.4 & Olsen et al. (2010) \\
\hline MSM05-712 & MSM5/5-712-2 & Fram Strait & 78.92 & 6.77 & -1487 & marine & IP25, dinocysts & 10514 & 458 & 140 & 4 & 4.0 & Müller et al. (2012); de Vernal et al. (2013) \\
\hline MSM05-723 & MSM5/5-723-2 & Fram Strait & 79.16 & 5.34 & -1349 & marine & IP25 & 7010 & 180 & 35 & 4 & 3.5 & Müller et al. (2012) \\
\hline ODP-684 & ODP 684 & Bjørn Drift & 61.00 & -25.00 & -1648 & marine & $\mathrm{Mg} / \mathrm{Ca}, \mathrm{d}^{18}$ O.foram & 10423 & 554 & 76 & 4 & 5.4 & Came et al. (2007) \\
\hline P1003 & P1003 & Norwegian Sea & 63.76 & 5.26 & -875 & marine & $\mathrm{d}^{18} \mathrm{O}$.foram, $\mathrm{d}^{18} \mathrm{O}$.foram & 7881 & -48 & 5 & 5 & 6.9 & Sejrup et al. (2011) \\
\hline PS2641 & PS2641-4 & E Greenland Shelf & 73.16 & 19.48 & -469 & marine & IP25 & 8780 & 20 & 19 & 2 & 0.8 & Müller et al. (2012) \\
\hline RAPID-12 & RAPID-12-1k & NE North Atlantic & 62.09 & -17.82 & -1938 & marine & $\mathrm{d}^{18} \mathrm{O}$. foram. $\mathrm{Mg} / \mathrm{Ca}, \mathrm{Mg} / \mathrm{Ca}$ & 11869 & 0 & 59 & 4 & 2.7 & Thournally et al. (2009) \\
\hline starvatn & Starvatn & Faroe Islands & 62.05 & -6.59 & 94 & lake & $\mathrm{BSi}$, flux_grains & 11077 & 1521 & 43 & 1 & 0.8 & Andresen et al. (2006) \\
\hline Troll28-03 & Troll 28-03 & North Sea & 60.87 & 3.73 & -345 & marine & forams, $\mathrm{d}^{18}$ O.foram & 9800 & 240 & 133 & 4 & 2.5 & Klitgaard-Kristensen et al. (2001); Sejrup et al. (2004a) \\
\hline \multicolumn{14}{|c|}{ Russian Arctic } \\
\hline dolgoe & Dolgoe Lake & Northern Yakutia & 71.87 & 127.07 & & lake & $\mathrm{d}^{18}$ O.cellulose, pollen & 9952 & 11 & 223 & 3 & -0.8 & Wolfe et al. (2000) \\
\hline kharinei & Lake Kharinei & NE Russia & 67.36 & 62.75 & 108 & lake & pollen, chironomids & 11503 & -44 & 117 & 2 & -4.1 & Jones et al. (2011); Salonen et al. (2011) \\
\hline lyadhej-to & Lake Lyadhej-To & NE Russia & 68.25 & 65.79 & & lake & chironomids, pollen & 10788 & 69 & 182 & 3 & -1.7 & Andreev et al. (2005) \\
\hline PL-96 & PL-96-112 BC & North of Kola Peninsula & 71.74 & 42.61 & -286 & marine & dinocysts & 8561 & 203 & 149 & 2 & 0.2 & Voronina et al. (2001); de Vernal et al. (2013) \\
\hline sysy-kyuele & Lake Sysy-Kyuele & E Siberia & 69.40 & 123.83 & 81 & lake & diatoms & 12670 & 62 & 391 & 1 & -3.0 & Biskaborn et al. (2012) \\
\hline
\end{tabular}

determined by the original studies into a structured format designed to facilitate comparison with climate model output. The fields are (1) climate variable - the climate variable (one or more), e.g. temperature, precipitation, wind, and/or effective moisture (precipitation - evapotranspiration; $\mathrm{P}-\mathrm{E}$ ). (2) Parameter detail - provides further detail about the basis on which the parameter is defined, e.g. air, sea surface, snow, lake bottom, and/or upwelling. (3) Seasonality - the time of year that is represented, e.g. MJJA (May-June-July-Agust), July, winter, warmest month, or annual. (4) Methodological detail - for quantitative reconstructions, this field denotes the transform function or other methodology used for calibration; for non-calibrated time series it is used to describe important or uncommon methodology used during record development. (5) Relation to climate parameter - the relation between the parameter and the interpreted climate variable, e.g. positive, negative, linear, or exponential. (6) Quantitative reconstruction - "quantitative" proxies have been transformed or otherwise calibrated to quantitative estimates of temperature $\left({ }^{\circ} \mathrm{C}\right)$, precipitation $\left(\mathrm{mm}\right.$ year $\left.{ }^{-1}\right)$ or other climate variables, whereas " uncalibrated" proxies have a clear relation to one or more climate variables, but have not been transformed into quantitative estimates.

Geochronology accuracy score. The vast majority (93\%) of the proxy records in this database are from Holocene sediments sampled from lakes and oceans. Because the sediment in these environments accumulates relatively continuously, the ages of samples between dated horizons can be interpolated with reasonable certainty. For these materials, ${ }^{14} \mathrm{C}$ analysis is the primary source of the geochronology. To rate the accuracy of age models from ${ }^{14} \mathrm{C}$-dated sediment sequences, we developed a procedure that is systematic and reproducible and that focuses on the most important factors that determine the overall accuracy (Appendix A). To facilitate its widespread utility, the simple algorithm is written in the open-source statistical package, $\mathrm{R}$ (available at: http://www.cefns.nau.edu/ npm4/). The score is based on the most basic and frequently published information about the materials used for ${ }^{14} \mathrm{C}$ analyses and the resulting age-depth trends. The input variables are (1) the original ${ }^{14} \mathrm{C}$ ages, including their analytical uncertainties; (2) the age of the core surface (sediment-water interface) if known; (3) sample depths in the core; (4) number of ages rejected by the original author; and (5) material type (one category for the suite of ages; Appendix A).

The accuracy of sedimentary age models depends on the extent to which the constraining ages reliably represent the true timing of sedimentation. The precision of the analyses (the laboratory-reported counting error) might account for only a small part of the overall uncertainty. More important is the extent to which the material dated actually represents the age of the downcore property of interest. Dissolved carbon derived from old sources and incorporated into organisms and minerals that grow in the water (the so-called "hardwater effect"), or the lag between when an organism grows versus the time it is incorporated into the sedimentary sequence (built-in age) can result in ages that are older than the true age, whereas post-depositional contamination by younger carbon can result in ages that are too young. Many studies have demonstrated the systematic offset between ${ }^{14} \mathrm{C}$ ages of bulk sediment versus the ages of plant macrofossils and tephra layers that they contain (e.g. Wolfe et al., 2004; Grimm et al., 2009). The carbon within bulk sediment may be derived from multiple sources, some of which can be much older than the time of final deposition at the lake or ocean floor. For dating of marine sediments with ${ }^{14} \mathrm{C}$, determining the marine reservoir effect at a given location through time is an additional challenge. This uncertainty, which is caused by the mixing of old deep water with younger shallow water, may be on the order of several hundreds of years. Identification of well-dated tephras has overcome this problem in some cases.

The accuracy of the geochronology is also determined by the number of ages used to delineate the trend in sedimentation rate relative to the extent to which the sedimentation rate varies at a core site. Where sediment accumulates uniformly through time, fewer ages are needed to determine the trend than for basins that experience variable sedimentation 

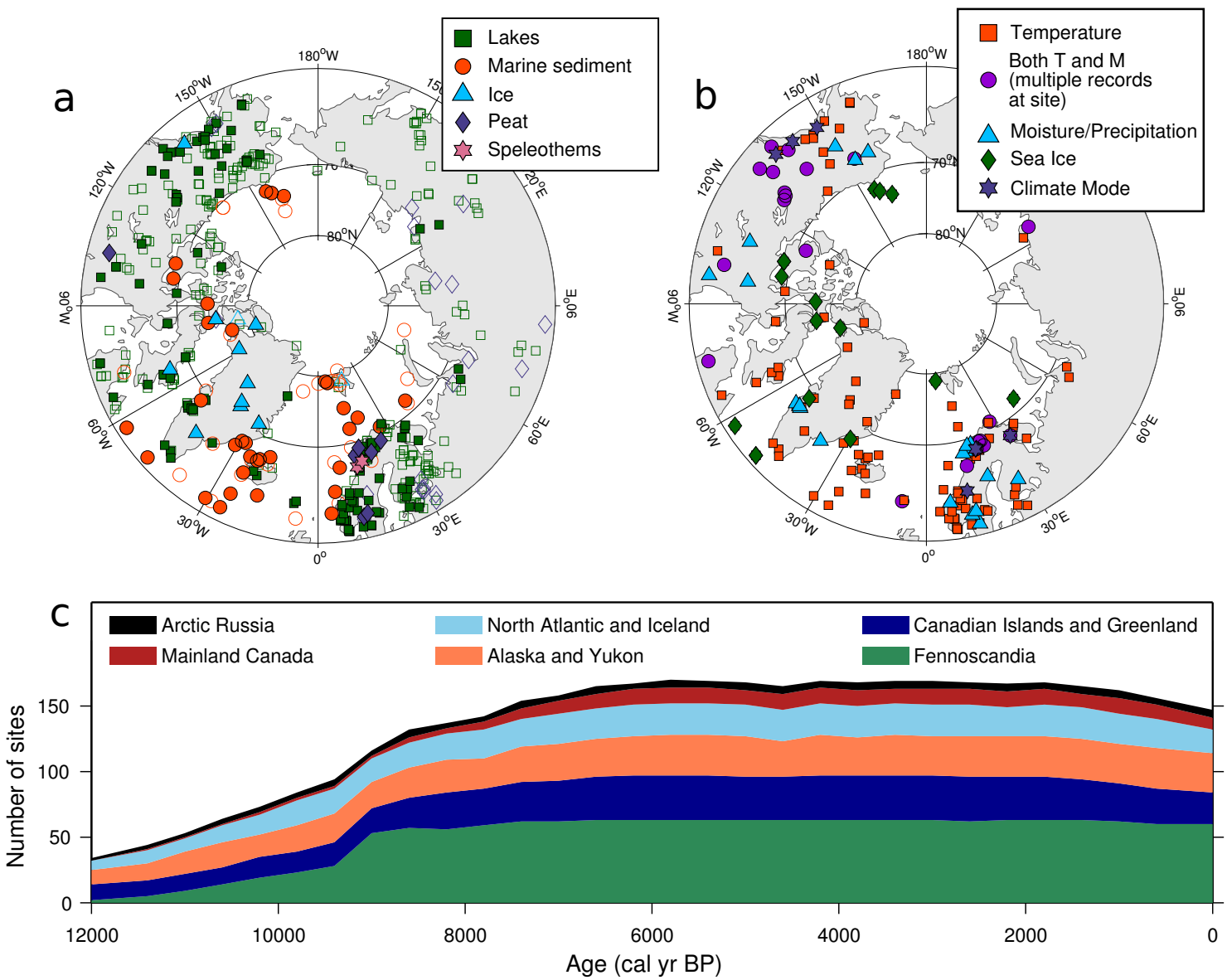

Figure 2. Location of proxy records in this database. (a) Sites that meet the criteria for inclusion in this database (solid symbols) and those that did not (open symbols) plotted by material/archive type. (b) Sites that meet the criteria plotted by broadly categorized climate variables ( $T$ and $M$ : temperature and moisture variables of all types, respectively). (c) Number of sites showing the time period they cover and subdivided by region. Some sites have more than one time series representing different climate variables. Information about each site is listed in Table 1 (accepted records) and Supplement Table S1 (excluded records).

rates. Previous studies that have included an assessment of geochronological accuracy have relied on the difference between the age of the nearest dated sample and the event of interest (e.g. Blois et al., 2011). This strategy is difficult to implement for studies that do not focus on a particular time slice. In addition, the approach assumes that each ${ }^{14} \mathrm{C}$ age is equally accurate, rather than assuming that different ages might have different accuracies and that the overall trend defined by several ages might average out the random errors or shift a biased age toward the more accurate ages in a series.

The chron scores for the 150 age models in the database range from -4.2 to 6.9 and average $0.8 \pm 2.1(1 \sigma)$, with higher values signifying more accurate age models (Table 1). Using the weighting factors listed in Appendix A, the chron scores correlate about equally with the delineation of the downcore trends ( $D$ values; $r=0.77$ ) and sample quality ( $Q$ values; $r=0.78$ ), and less with the precision ( $P$ values; $r=0.53$ ). The weightings can be modified to emphasize any of the variables. We recognize that judging the quality of sample material and weighting the various factors that influence accuracy is subjective. Nonetheless, the rating scheme explicitly recognizes the key factors that influence the geochronological accuracy of sedimentary sequences that do not lend themselves to conventional statistical approaches, and assigns reasonable numerical ratings based on a simple, reproducible, and customizable procedure.

\section{Database contents}

\subsection{Number, distribution and resolution of records}

The records included in this database were largely identified through literature searches as part of previous Arctic Holocene syntheses (e.g. Kaufman et al., 2004; Sundqvist et al., 2010), and from the NOAA Paleoclimatology and PANGAEA databases. We searched these archives for all records located north of $58^{\circ} \mathrm{N}$ latitude that span from at least 6 to 


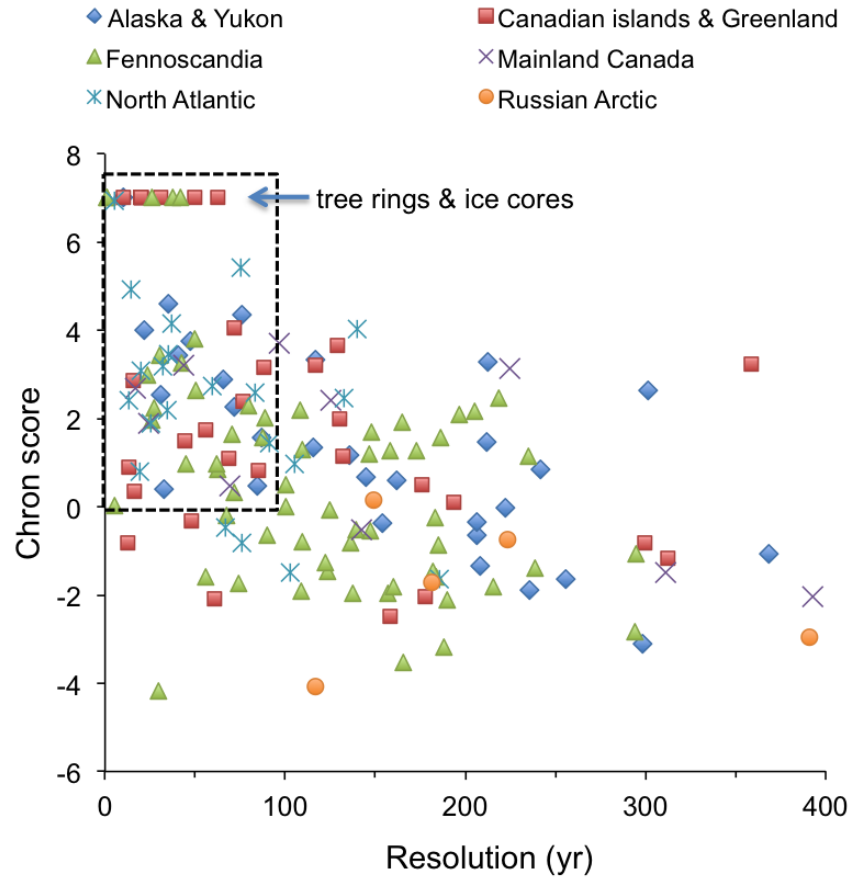

Figure 3. Geochronology accuracy score (chron score) versus sampling resolution for records in the database. Records from trees and glacier ice are arbitrarily assigned a chron score of 7 . Highly resolved records (better than 100 years on average) with high chron scores $(>0)$ are enclosed by the square and their location is plotted in Fig. 4.

$2 \mathrm{ka}$, but most of the records did not meet the criteria for inclusion in our database. We considered proxy records from nearly 500 sites (Fig. 2a). Of these, records from 170 sites met the stated criteria (Table 1) and 326 did not (Supplement Table S1). Many sites include more than one proxy record and the metadata for each time series are listed individually in Table 2.

The geographical distribution of the accepted records is far from uniform (Fig. 2b). The density of sites is comparatively high in Fennoscandia (65), the Canadian Arctic Archipelago and Greenland (35), Alaska and Yukon (30), and the North Atlantic (24). Coverage of sites that meet our criteria in mainland Canada is sparse (12), and we found only a few records in all of the Russian Arctic that meet the specified criteria (5). The lack of available data from the Russian Arctic, the largest Arctic landmass, is striking. Although we reviewed many published climate reconstructions from the region, most had insufficient temporal resolution or geochronological control, and most lack digital data (Kheshgi and Lapenis, 1996). Digitizing the data from the published graphs is not satisfactory because the time series for many of the Russian Arctic records appear to be drawn by hand rather than by a specified, reproducible mathematical routine, and without displaying the underlying time-series data.
The resolution of a proxy time series depends on its sample resolution along with the time averaging inherent within a given proxy. For example, sediment that accumulates in small lakes integrates climate conditions over a longer timescale than does the ice comprising an annual layer of a glacier. While keeping this limitation in mind, we can summarize the temporal resolution of proxy time series in the database (Fig. 3). Except for the Russian Arctic, records with subcentennial resolution are available from all regions. At decadal resolution, only eight sites are available. Generally, productivity indicators such as biogenic silica and organicmatter content are more highly resolved than palaeoecological data (e.g. pollen, diatoms, chironomids). Areas with comparatively high density of records with decadal resolution include Fennoscandia, the Canadian Arctic Archipelago and Greenland, and Alaska and Yukon.

\subsection{Proxy types}

The database includes records from all types of natural archives that have been analysed for a variety of physical and biological properties. Each proxy has a characteristic response time and sensitivity to climatic variations, and each responds to different aspects of climate. Different proxies from the same geological archive can therefore yield different inferences about the nature, timing and magnitude of palaeoclimatic change. The types of proxy records and their sources are briefly summarized below.

\subsubsection{Lake sediments}

Most $(60 \%)$ of the records come from lake sediments. Lakes are the most widely distributed source of proxy climate information from the Arctic. They provide a continuous archive of climate-sensitive materials that originated within the lake (e.g. aquatic biota such as diatoms and chironomid remains) or from the surrounding catchment (e.g. pollen). Arctic lakes are sensitive to climatic changes because relatively small shifts in, for example, temperature impact duration of ice cover, the radiation and water balance of lakes, and the physical, chemical, and biological characteristics of their catchments, often resulting in major shifts in limnology (e.g. Smol and Douglas, 2007). The records in this database rely on sedimentological, biological, and isotopic indicators including chironomid, diatom, and pollen assemblages; spectrally inferred sedimentary chlorophyll $a$; biogenic-silica content; dry bulk density; ostracode magnesium-to-calcium ratio $(\mathrm{Mg} / \mathrm{Ca})$; oxygen isotope composition $\left(\delta^{18} \mathrm{O}\right)$; assemblages of microfossils; and the carbon isotope ratio $\left(\delta^{13} \mathrm{C}\right)$ of bulk organic matter. Many proxies reflect changes in summer temperatures, a primary control on many physical and biological processes in lakes at high latitudes. Some reflect other aspects of the climate system, including nutrient availability, length of the growing season, length of the ice-free season, windiness, and storm-track trajectories, to name a few. Lakes 
Table 2. Proxy records in the database arranged by six Arctic regions. See Table 1 for information about each site. (Notes. See Table 1 for explanation of punctuation and abbreviations for proxy types; see text for discussion of "proxy climate variable"; site short name: title of tab in excel spreadsheet - database with proxy and geochronology data; vplR record: time series heading within the proxy data sheet; statistical detail abbreviations as follows: ML: maximum likelihood, MAT: modern analog technique, RESP: response surface, PLS: partial least squares, SDF: speleothem delta function, WAPLS: weighted-average partial least squares; unit abbreviations as follows: smow: standard mean ocean water, pdb: pee dee belemnite, cgs: centimeter-gram-second system, psu: practical salinity unit; climate variable explanations as follows: ELA: equilibrium-line altitude, eff: effective.)

\begin{tabular}{|c|c|c|c|c|c|c|c|c|c|}
\hline \multirow[b]{2}{*}{$\begin{array}{l}\text { Site } \\
\text { short name }\end{array}$} & \multirow[b]{2}{*}{ Proxy } & \multirow[b]{2}{*}{$\begin{array}{l}\text { vplR } \\
\text { record }\end{array}$} & \multirow[b]{2}{*}{ Units } & \multicolumn{6}{|c|}{ Proxy climate variable } \\
\hline & & & & $\begin{array}{l}\text { Climate } \\
\text { variable }\end{array}$ & $\begin{array}{l}\text { Climate } \\
\text { variable detail }\end{array}$ & Seasonality & $\begin{array}{l}\text { Statistical } \\
\text { detail }\end{array}$ & Relation & $\begin{array}{l}\text { Quantitative } \\
\text { reconstruction }\end{array}$ \\
\hline \multicolumn{10}{|c|}{ Alaska and Yukon } \\
\hline andy & pollen & precip & $\mathrm{mm}$ & precip & rain + snow & annual & MAT & positive & $\mathrm{X}$ \\
\hline andy & pollen & temp & ${ }^{\circ} \mathrm{C}$ & temp & air & coldest & MAT & positive & $\mathrm{X}$ \\
\hline andy & pollen & temp & ${ }^{\circ} \mathrm{C}$ & temp & air & warmest & MAT & positive & $\mathrm{X}$ \\
\hline bells & pollen & precip & $\mathrm{mm}$ & precip & rain + snow & annual & MAT & positive & $\mathrm{X}$ \\
\hline bells & pollen & temp & ${ }^{\circ} \mathrm{C}$ & temp & air & coldest & MAT & positive & $\mathrm{X}$ \\
\hline bells & pollen & temp & ${ }^{\circ} \mathrm{C}$ & temp & air & warmest & MAT & positive & $\mathrm{X}$ \\
\hline candelabra & pollen & precip & $\mathrm{mm}$ & precip & rain + snow & annual & MAT & positive & $\mathrm{X}$ \\
\hline candelabra & pollen & temp & ${ }^{\circ} \mathrm{C}$ & temp & air & coldest & MAT & positive & $\mathrm{X}$ \\
\hline candelabra & pollen & temp & ${ }^{\circ} \mathrm{C}$ & temp & air & warmest & MAT & positive & $\mathrm{X}$ \\
\hline dune & $\mathrm{d}^{13}$ C.bulk_organics & $\mathrm{d}^{13} \mathrm{C}$ & permil & moisture & eff & annual & mean & negative & \\
\hline farewell & MgCa.ostracodes & $\mathrm{Mg} / \mathrm{Ca}$ & $\mathrm{mmol} \mathrm{mol}^{-1}$ & temp & lake_surface & summer & mean & positive & \\
\hline GGC19 & dinocysts & sea_ice_months & months year ${ }^{-1}$ & ice & sea & annual & MAT & positive & $\mathrm{X}$ \\
\hline GGC19 & dinocysts & sea_ice_conc & $0-10$ & ice & sea & annual & MAT & positive & $\mathrm{X}$ \\
\hline GGC19 & dinocysts & salinity & psu & salinity & sea_surface & summer & MAT & positive & $\mathrm{X}$ \\
\hline GGC19 & dinocysts & salinity & psu & salinity & sea_surface & winter & MAT & positive & $\mathrm{X}$ \\
\hline GGC19 & $\mathrm{d}^{18}$ O.forams & temp & $\circ$ & temp & bottom water & annual & & positive & $\mathrm{X}$ \\
\hline GGC19 & $\mathrm{d}^{18}$ O.forams & temp & ${ }^{\circ} \mathrm{C}$ & temp & sea_surface & annual & mean & positive & $\mathrm{X}$ \\
\hline GGC19 & dinocysts & temp & ${ }^{\circ} \mathrm{C}$ & temp & sea_surface & summer & MAT & positive & $\mathrm{X}$ \\
\hline GGC19 & dinocysts & temp & ${ }^{\circ} \mathrm{C}$ & temp & sea_surface & winter & MAT & positive & $\mathrm{X}$ \\
\hline greyling & $\mathrm{OM}$ & $\mathrm{OM}$ & $\%$ & ELA & glacier & annual & mean & positive & \\
\hline hail & pollen & precip & $\mathrm{mm}$ & precip & rain + snow & annual & MAT & positive & $\mathrm{X}$ \\
\hline hail & pollen & temp & $\circ$ & temp & air & coldest & MAT & positive & $\mathrm{X}$ \\
\hline hail & pollen & temp & $\circ$ & temp & air & warmest & MAT & positive & $\mathrm{X}$ \\
\hline hallet & $\mathrm{OM}$ & $\mathrm{OM}$ & $\%$ & ELA & glacier & annual & mean & positive & \\
\hline hallet & $\mathrm{BSi}$ & $\mathrm{BSi}$ & $\mathrm{mg} \mathrm{g}^{-1}$ & temp & air & summer & mean & positive & \\
\hline HLY0501 & dinocysts & sea_ice_months & months year ${ }^{-1}$ & ice & sea & annual & MAT & positive & $\mathrm{X}$ \\
\hline HLY0501 & dinocysts & sea_ice_conc & $0-10$ & ice & sea & annual & MAT & positive & $\mathrm{X}$ \\
\hline HLY0501 & dinocysts & salinity & psu & salinity & sea_surface & summer & MAT & positive & $\mathrm{X}$ \\
\hline HLY0501 & dinocysts & salinity & psu & salinity & sea_surface & winter & MAT & positive & $\mathrm{X}$ \\
\hline HLY0501 & dinocysts & temp & $\circ$ & temp & sea_surface & summer & MAT & positive & $\mathrm{X}$ \\
\hline HLY0501 & dinocysts & temp & $\circ$ & temp & sea_surface & winter & MAT & positive & $\mathrm{X}$ \\
\hline honeymoon & pollen & precip & $\mathrm{mm}$ & precip & rain + snow & annual & MAT & positive & $\mathrm{X}$ \\
\hline honeymoon & pollen & temp & $\circ$ & temp & air & coldest & MAT & positive & $\mathrm{X}$ \\
\hline honeymoon & pollen & temp & $\circ$ & temp & air & warmest & MAT & positive & $\mathrm{X}$ \\
\hline hudson & chironomids & temp & $\circ$ & temp & air & July & WAPLS2 & positive & $\mathrm{X}$ \\
\hline jellybean & $\mathrm{d}^{18}$ O.calcite & $\mathrm{d}^{18} \mathrm{O}$ & permil & mode & Aleutian_low & winter & mean & negative & \\
\hline kusawa & $\mathrm{BSi}$ & $\mathrm{BSi}$ & $\%$ & temp & air & summer & mean & positive & \\
\hline lily & pollen & precip & $\mathrm{mm}$ & precip & rain + snow & annual & MAT & positive & $\mathrm{X}$ \\
\hline lily & pollen & temp & $\circ$ & temp & air & coldest & MAT & positive & $\mathrm{X}$ \\
\hline lily & pollen & temp & $\circ$ & temp & air & warmest & MAT & positive & $\mathrm{X}$ \\
\hline logan & $\mathrm{d}^{18} \mathrm{O}$.ice & $\mathrm{d}^{18} \mathrm{O}$ & permil & mode & Aleutian_low & winter & mean & negative & \\
\hline lonespruce & $\mathrm{BSi}$ & $\mathrm{BSi}$ & $\%$ & temp & air & growing & mean & positive & \\
\hline meleze & pollen & precip & $\mathrm{mm}$ & precip & rain + snow & annual & MAT & positive & $\mathrm{X}$ \\
\hline meleze & pollen & temp & $\circ$ & temp & air & coldest & MAT & positive & $\mathrm{X}$ \\
\hline meleze & pollen & temp & $\circ$ & temp & air & warmest & MAT & positive & $\mathrm{X}$ \\
\hline mica & $\mathrm{d}^{18}$ O.diatom & $\mathrm{d}^{18} \mathrm{O}$ & permil & mode & Aleutian_low & winter & mean & positive & \\
\hline moose & chironomids & temp & $\circ$ & temp & air & July & WAPLS & positive & $\mathrm{X}$ \\
\hline P1B3 & dinocysts & sea_ice_conc & $0-10$ & ice & sea & annual & MAT & positive & $\mathrm{X}$ \\
\hline P1B3 & dinocysts & sea_ice_months & months year $^{-1}$ & ice & sea & annual & months & positive & $\mathrm{X}$ \\
\hline P1B3 & dinocysts & salinity & psu & salinity & sea_surface & summer & MAT & positive & $\mathrm{X}$ \\
\hline P1B3 & dinocysts & salinity & psu & salinity & sea_surface & winter & MAT & positive & $\mathrm{X}$ \\
\hline P1B3 & dinocysts & temp & o & temp & sea_surface & summer & MAT & positive & $\mathrm{X}$ \\
\hline P1B3 & dinocysts & temp & $\circ$ & temp & sea_surface & winter & MAT & positive & $\mathrm{X}$ \\
\hline quartz & chironomids & temp & $\circ$ & temp & air & July & WAPLS2 & positive & $\mathrm{X}$ \\
\hline rainbow & chironomids & temp & $\circ$ & temp & air & July & WAPLS2 & positive & $\mathrm{X}$ \\
\hline ranger & pollen & precip & $\mathrm{mm}$ & precip & rain + snow & annual & MAT & positive & $\mathrm{X}$ \\
\hline ranger & pollen & temp & $\circ$ & temp & air & coldest & MAT & positive & $\mathrm{X}$ \\
\hline ranger & pollen & temp & $\circ$ & temp & air & warmest & MAT & positive & $\mathrm{X}$ \\
\hline screaminglynx & chironomids & temp & $\circ$ & temp & air & July & WAPLS2 & positive & $\mathrm{X}$ \\
\hline takahula & $\mathrm{d}^{18}$ O.calcite & $\mathrm{d}^{18} \mathrm{O}$ & permil & moisture & eff & annual & mean & negative & \\
\hline trout & chironomids & temp & o & temp & air & July & WAPLS & positive & $\mathrm{X}$ \\
\hline trout & chironomids & temp & $\circ$ & temp & air & July & WAPLS & positive & $\mathrm{X}$ \\
\hline upper_fly & pollen & precip & $\mathrm{mm}$ & precip & rain + snow & annual & MAT & positive & $\mathrm{X}$ \\
\hline upper_fly & pollen & temp & $\circ$ & temp & air & July & MAT & positive & $X$ \\
\hline waskey & DBD & bulk density & $\mathrm{g} \mathrm{cm}^{-3}$ & temp & air & summer & mean & negative & \\
\hline wolverine & MAR & MAR & $\mathrm{g} \mathrm{cm}^{-2}$ year $^{-1}$ & moisture & eff & annual & sum & negative & \\
\hline
\end{tabular}


Table 2. Continued.

\begin{tabular}{|c|c|c|c|c|c|c|c|c|c|}
\hline \multicolumn{10}{|c|}{ Canadian islands and Greenland } \\
\hline agassiz & $\mathrm{d}^{18}$ O.ice & $\mathrm{d}^{18} \mathrm{O}$ & permil & temp & air & annual & mean & positive & \\
\hline agassiz & $\mathrm{d}^{18}$ O.ice & $\mathrm{d}^{18} \mathrm{O}$ & permil & temp & air & annual & mean & positive & \\
\hline agassiz & $\mathrm{d}^{18}$ O.ice & $\mathrm{d}^{18} \mathrm{O}$ & permil & temp & air & annual & mean & positive & \\
\hline agassiz & $\mathrm{d}^{18} \mathrm{O}$.ice & $\mathrm{d}^{18} \mathrm{O}$ & permil & temp & air & annual & mean & positive & \\
\hline agassiz & ice.melt & ice_melt_fraction & $\%$ & temp & air & summer & mean & positive & \\
\hline akvaquak & pollen & $\operatorname{sun}_{-}^{-}$frac & unitless & sun & surface & JJAS & MAT & positive & $\mathrm{X}$ \\
\hline akvaquak & pollen & sun_frac_max & unitless & sun & surface & JJAS & maxMAT & positive & $\mathrm{X}$ \\
\hline akvaquak & pollen & sun_frac_min & unitless & sun & surface & JJAS & minMAT & positive & $\mathrm{X}$ \\
\hline akvaquak & pollen & temp & $\circ$ & temp & air & July & MAT & positive & $\mathrm{X}$ \\
\hline akvaquak & pollen & temp_max & $\circ$ & temp & air & July & maxMAT & positive & $\mathrm{X}$ \\
\hline akvaquak & pollen & temp_min & $\circ$ & temp & air & July & $\operatorname{minMAT}$ & positive & $\mathrm{X}$ \\
\hline ARC3 & IP25 & IP25_flux & $\mu \mathrm{g} \mathrm{cm}^{-2}$ year $^{-1}$ & ice & sea & spring & occurrence & positive & \\
\hline $\mathrm{BC} 01$ & $\mathrm{OM}$ & OM & $\%$ & temp & air & summer & mean & positive & \\
\hline $\mathrm{BC} 01$ & $\mathrm{BSi}$ & $\mathrm{BSi}$ & $\%$ & temp & air & summer & mean & positive & \\
\hline big_round & MS & MS & $\operatorname{cgs}$ & glacier & extent & annual & $\max$ & positive & \\
\hline braya_so & alkenones & Uk37 & index & temp & lake_surface & summer & mean & positive & \\
\hline century & $\mathrm{d}^{18} \mathrm{O}$. ice & $\mathrm{d}^{18} \mathrm{O}$ & permil.smow & temp & air & annual & mean & positive & \\
\hline DA05 & diatoms & sea_ice_diatoms & $\%$ & ice & sea & annual & MAT & positive & \\
\hline devon & $\mathrm{d}^{18}$ O.ice & $\mathrm{d}^{18} \mathrm{O}$ & permil.smow & temp & air & annual & mean & positive & \\
\hline Dye3 & $\mathrm{d}^{18}$ O.ice & $\mathrm{d}^{18} \mathrm{O}$ & permil.smow & temp & air & annual & mean & positive & \\
\hline flower_valley & $\mathrm{dD}$ & $\mathrm{dD}$ & permil & moisture & eff & annual & sum & positive & \\
\hline GISP2 & $\mathrm{d}^{18} \mathrm{O}$.ice & temp & $\circ$ & temp & air & annual & isotopes & positive & $\mathrm{X}$ \\
\hline GRIP & $\mathrm{d}^{18}$ O.ice & $d^{18} \mathrm{O}$ & permil.smow & temp & air & annual & mean & positive & \\
\hline hjort & chironomids & CCA1 & sd units & temp & air & summer & mean & negative & \\
\hline HU84 & dinocysts & sea_ice_months & months year $^{-1}$ & ice & sea & annual & MAT & positive & $\mathrm{X}$ \\
\hline HU84 & dinocysts & sea_ice_conc & $0-10$ & ice & sea & annual & MAT & positive & $\mathrm{X}$ \\
\hline HU84 & dinocysts & salinity & psu & salinity & sea_surface & summer & MAT & positive & $\mathrm{X}$ \\
\hline HU84 & dinocysts & salinity & psu & salinity & sea_surface & winter & MAT & positive & $\mathrm{X}$ \\
\hline HU84 & dinocysts & temp & $\circ$ & temp & sea_surface & summer & MAT & positive & $\mathrm{X}$ \\
\hline HU84 & dinocysts & temp & $\circ$ & temp & sea_surface & winter & MAT & positive & $\mathrm{X}$ \\
\hline HU90 & dinocysts & sea_ice_months & months year $^{-1}$ & ice & sea & annual & MAT & positive & $\mathrm{X}$ \\
\hline HU90 & dinocysts & sea_ice_conc & $0-10$ & ice & sea & annual & MAT & positive & $\mathrm{X}$ \\
\hline HU90 & dinocysts & salinity & psu & salinity & sea_surface & summer & MAT & positive & $\mathrm{X}$ \\
\hline HU90 & dinocysts & salinity & psu & salinity & sea_surface & winter & MAT & positive & $\mathrm{X}$ \\
\hline HU90 & dinocysts & temp & $\circ$ & temp & sea_surface & summer & MAT & positive & $\mathrm{X}$ \\
\hline HU90 & dinocysts & temp & $\circ$ & temp & sea_surface & winter & MAT & positive & $\mathrm{X}$ \\
\hline HU91 & dinocysts & sea_ice_months & months year $^{-1}$ & ice & sea & annual & MAT & positive & $\mathrm{X}$ \\
\hline HU91 & dinocysts & sea_ice_conc & $0-10$ & ice & sea & annual & MAT & positive & $\mathrm{X}$ \\
\hline HU91 & dinocysts & salinity & psu & salinity & sea_surface & summer & MAT & positive & $\mathrm{X}$ \\
\hline HU91 & dinocysts & salinity & psu & salinity & sea_surface & winter & MAT & positive & $\mathrm{X}$ \\
\hline HU91 & dinocysts & temp & $\circ$ & temp & sea_surface & summer & MAT & positive & $\mathrm{X}$ \\
\hline HU91 & dinocysts & temp & $\circ$ & temp & sea_surface & winter & MAT & positive & $\mathrm{X}$ \\
\hline igaliku & pollen.flux & pollen_count & $\mathrm{g} \mathrm{cm}^{-2}$ year $^{-1}$ & temp & air & summer & mean & positive & \\
\hline iglutalik & pollen & temp & $\circ$ & temp & air & July & RESP & positive & $\mathrm{X}$ \\
\hline jake & pollen & temp & $\circ$ & temp & air & July & RESP & positive & $\mathrm{X}$ \\
\hline LS009 & dinocysts & sea_ice_months & months year $^{-1}$ & ice & sea & annual & MAT & positive & $\mathrm{X}$ \\
\hline LS009 & dinocysts & sea ice conc & $0-10$ & ice & sea & annual & MAT & positive & $\mathrm{X}$ \\
\hline LS009 & dinocysts & salinity & psu & salinity & sea_surface & summer & MAT & positive & $\mathrm{X}$ \\
\hline LS009 & dinocysts & salinity & psu & salinity & sea_surface & winter & MAT & positive & $\mathrm{X}$ \\
\hline LS009 & dinocysts & temp & $\circ$ & temp & sea_surface & summer & MAT & positive & $\mathrm{X}$ \\
\hline LSO09 & dinocysts & temp & $\circ$ & temp & sea_surface & winter & MAT & positive & $\mathrm{X}$ \\
\hline MD99-2227 & dinocysts & sea_ice_months & months year ${ }^{-1}$ & ice & sea & annual & MAT & positive & $\mathrm{X}$ \\
\hline MD99-2227 & dinocysts & sea_ice_conc & $0-10$ & ice & sea & annual & MAT & positive & $\mathrm{X}$ \\
\hline MD99-2227 & dinocysts & salinity & psu & salinity & sea_surface & summer & MAT & positive & $\mathrm{X}$ \\
\hline MD99-2227 & dinocysts & salinity & psu & salinity & sea_surface & winter & MAT & positive & $\mathrm{X}$ \\
\hline MD99-2227 & dinocysts & temp & $\circ$ & temp & sea_surface & summer & MAT & positive & $\mathrm{X}$ \\
\hline MD99-2227 & dinocysts & temp & $\circ$ & temp & sea_surface & winter & MAT & positive & $\mathrm{X}$ \\
\hline N14 & $\mathrm{BSi}$ & Bsi & $\%$ & precipitation & all & annual & & positive & \\
\hline naujg1 & mineral.content & ROI & $\%$ & temp & air & summer & mean & positive & \\
\hline NGRIP & $\mathrm{d}^{18} \mathrm{O}$. ice & $d^{18} \mathrm{O}$ & permil.smow & temp & air & annual & mean & positive & \\
\hline north & chironomids & temp & $\circ$ & temp & air & July & WAT & positive & $\mathrm{X}$ \\
\hline north & $\mathrm{OM}$ & $\mathrm{OM}$ & $\%$ & temp & air & summer & mean & positive & \\
\hline north & $\mathrm{BSi}$ & $\mathrm{BSi}$ & $\%$ & temp & air & summer & mean & positive & \\
\hline penny & $\mathrm{d}^{18}$ O.ice & $d^{18} \mathrm{O}$ & permil & temp & air & annual & mean & positive & \\
\hline penny & $\mathrm{d}^{18} \mathrm{O}$.ice & $\mathrm{d}^{18} \mathrm{O}$ & permil & temp & air & annual & mean & positive & \\
\hline qipisirargo & pollen & sun_frac & unitless & sun & surface & JJAS & MAT & positive & $\mathrm{X}$ \\
\hline qipisirargo & pollen & sun_frac_max & unitless & sun & surface & JJAS & maxMAT & positive & $\mathrm{X}$ \\
\hline qipisirargo & pollen & sun_frac_min & unitless & sun & surface & JJAS & minMAT & positive & $\mathrm{X}$ \\
\hline qipisirargo & pollen & temp & $\circ$ & temp & air & July & MAT & positive & $\mathrm{X}$ \\
\hline qipisirargo & pollen & temp_max & $\circ$ & temp & air & July & maxMAT & positive & $\mathrm{X}$ \\
\hline qipisirargo & pollen & temp_min & $\circ$ & temp & air & July & $\operatorname{minMAT}$ & positive & $\mathrm{X}$ \\
\hline renland & $\mathrm{d}^{18} \mathrm{O}$ & $\mathrm{d}^{18} \mathrm{O}$ & permil & temp & air & annual & mean & positive & \\
\hline sfl4-1 & $\mathrm{OM}$ & OM & $\%$ & temp & air & summer & mean & positive & \\
\hline SP02 & $\mathrm{OM}$ & OM & $\%$ & temp & air & summer & mean & positive & \\
\hline SS1381 & mineral.flux & mineral_flux & $\mathrm{g} \mathrm{cm}^{-2}$ year $^{-1}$ & moisture & eff & annual & sum & positive & \\
\hline SS 16 & diatoms & CCA1 & unitless & moisture & eff & annual & sum & positive & \\
\hline SS49 & diatoms & CCA1 & unitless & moisutre & eff & annual & sum & positive & \\
\hline SS8 & mineral.flux & mineral_flux & $\mathrm{g} \mathrm{cm}^{-2}$ year $^{-1}$ & moisture & eff & annual & sum & positive & \\
\hline
\end{tabular}


Table 2. Continued.

\begin{tabular}{|c|c|c|c|c|c|c|c|c|c|}
\hline \multicolumn{10}{|l|}{ Fennoscandia } \\
\hline arapisto & pollen & temp & $\circ$ & temp & air & annual & WAPLS & positive & $\mathrm{X}$ \\
\hline austerkjosen & pollen & temp & $\circ$ & temp & air & July & WAPLS & positive & $\mathrm{X}$ \\
\hline berkut & chironomids & temp & $\circ$ & temp & air & July & WAPLS & positive & $\mathrm{X}$ \\
\hline bjornfjelltjorn & pollen & temp & $\circ$ & temp & air & July & WAPLS & positive & $\mathrm{X}$ \\
\hline brurskardstjorni & chironomids & temp & $\circ$ & temp & air & July & WAPLS & positive & $\mathrm{X}$ \\
\hline chuna & $\mathrm{d}^{18}$ O.diatoms & $\mathrm{d}^{18} \mathrm{O}$ & permil & mode & NAO & winter & & positive & \\
\hline chuna & pollen & precip & $\mathrm{mm}$ & precip & rain + snow & annual & MAT & positive & $\mathrm{X}$ \\
\hline chuna & pollen & temp & $\circ$ & temp & air & July & MAT & positive & $\mathrm{X}$ \\
\hline dalene & pollen & temp & $\circ$ & temp & air & July & WAPLS & positive & $\mathrm{X}$ \\
\hline dalmutladdo & pollen & precip & $\mathrm{mm}$ & precip & rain + snow & annual & WAPLS & positive & $\mathrm{X}$ \\
\hline dalmutladdo & pollen & temp & $\circ$ & temp & air & January & WAPLS & positive & $\mathrm{X}$ \\
\hline dalmutladdo & pollen & temp & $\circ$ & temp & air & July & WAPLS & positive & $\mathrm{X}$ \\
\hline dravladalsvatn & DBD & ELA & $\mathrm{mm}$ & ELA & glacier & annual & mean & negative & $\mathrm{X}$ \\
\hline fauske & $\mathrm{d}^{18} \mathrm{O}$ & $d^{18} \mathrm{O}$ & permil & temp & air & annual & mean & negative & \\
\hline Fiskebolvatnet & mass.flux & MAR & $\mathrm{g} \mathrm{cm}^{-2}$ year $^{-1}$ & moisture & eff & annual & sum & positive & \\
\hline Flarken & pollen & temp & - & temp & air & annual & WAPLS & positive & $\mathrm{X}$ \\
\hline flotatjonn & pollen & temp & $\circ$ & temp & air & July & WAPLS & positive & $\mathrm{X}$ \\
\hline gammelheimvatnet & pollen & temp & $\circ$ & temp & air & July & WAPLS & positive & $\mathrm{X}$ \\
\hline gilltjarnen & pollen & temp & $\circ$ & temp & air & annual & mean & positive & $\mathrm{X}$ \\
\hline gilltjarnen & chironomids & temp & $\circ$ & temp & air & July & WAPLS & positive & $\mathrm{X}$ \\
\hline gloppsjon & pollen & temp & $\circ$ & temp & air & annual & WAPLS & positive & $\mathrm{X}$ \\
\hline grostjorn & pollen & temp & $\circ$ & temp & air & July & WAPLS & positive & $\mathrm{X}$ \\
\hline gunnarsfjorden & pollen & GDD & $\circ$ & grow_deg_day & air & summer & DA & positive & $\mathrm{X}$ \\
\hline gunnarsfjorden & pollen & precip & $\mathrm{mm}$ & precip & rain + snow & summer & DA & positive & $\mathrm{X}$ \\
\hline gunnarsfjorden & pollen & precip & $\mathrm{mm}$ & precip & rain + snow & winter & DA & positive & $\mathrm{X}$ \\
\hline gunnarsfjorden & pollen & AET/PET & unitless & precip & eff & annual & sum & positive & $\mathrm{X}$ \\
\hline gunnarsfjorden & pollen & temp & $\circ$ & temp & air & coldest & mean & positive & $\mathrm{X}$ \\
\hline gunnarsfjorden & pollen & temp & $\circ$ & temp & air & warmest & mean & positive & $\mathrm{X}$ \\
\hline haugtjern & pollen & temp & $\circ$ & temp & air & July & WAPLS & positive & $\mathrm{X}$ \\
\hline holebudalen & pollen & temp & $\circ$ & temp & air & July & WAPLS & positive & $\mathrm{X}$ \\
\hline holebudalen & chironomids & temp & $\circ$ & temp & lake_surface & July & WAPLS & positive & $\mathrm{X}$ \\
\hline igelsjon & $\mathrm{d}^{18}$ O.calcite & $\mathrm{d}^{18} \mathrm{O}$ & permil.pdb & moisutre & eff & annual & sum & negative & \\
\hline isbenttjonn & pollen & temp & 。 & temp & air & July & WAPLS & positive & $\mathrm{X}$ \\
\hline jarburvatnet & OM & $\mathrm{OM}$ & $\%$ & ELA & glacier & annual & mean & positive & \\
\hline kinnshaugen & pollen & temp & $\circ$ & temp & air & July & WAPLS & positive & $\mathrm{X}$ \\
\hline kjennsvatn & DBD & ELA & $\mathrm{mm}$ & ELA & glacier & annual & mean & positive & $\mathrm{X}$ \\
\hline klotjarnen & pollen & temp & $\circ$ & temp & air & annual & WAPLS & positive & $\mathrm{X}$ \\
\hline kortlanda & humification_index & humification_index & abs & moisture & eff & annual & mean & negative & \\
\hline kortlanda & humification_index & humification_index & abs & moisture & eff & annual & mean & negative & \\
\hline KP2 & pollen & temp & 。 & temp & air & July & WAPLS & positive & $\mathrm{X}$ \\
\hline laihalampi & pollen & temp & $\circ$ & temp & air & annual & WAPLS & positive & $\mathrm{X}$ \\
\hline lake850 & $\mathrm{d}^{18}$ O.diatoms & $\mathrm{d}^{18} \mathrm{O}$ & permil & mode & & & & positive & \\
\hline lake850 & chironomids & temp & 。 & temp & air & July & WAPLS & positive & $\mathrm{X}$ \\
\hline lake850 & diatoms & temp & $\circ$ & temp & air & July & WAPLS & positive & $\mathrm{X}$ \\
\hline lapland & width & temp & $\circ$ & temp & air & July & linear & positive & $\mathrm{X}$ \\
\hline liltlvatn & pollen & temp & $\circ$ & temp & air & July & WAPLS & positive & $\mathrm{X}$ \\
\hline myrvatn & pollen & temp & $\circ$ & temp & air & July & WAPLS & positive & $\mathrm{X}$ \\
\hline nattmalsvatn & MS & MS & $\mathrm{m}^{-3} \mathrm{~kg}^{-1}$ & precip & rain + snow & winter & sum & positive & \\
\hline nautajarvi & pollen & temp & & temp & air & annual & WAPLS & positive & $\mathrm{X}$ \\
\hline nerfloen & multiproxyPCscore & $\mathrm{PCl}$ & unitless & precip & rain + snow & winter & sum & positive & \\
\hline njakajaure & diatoms & temp & $\circ$ & temp & air & July & WAPLS & positive & $\mathrm{X}$ \\
\hline njulla & diatoms & temp & $\circ$ & temp & air & July & WAPLS & positive & $\mathrm{X}$ \\
\hline njulla & chironomids & temp & $\circ$ & temp & air & July & WAPLS & positive & $\mathrm{X}$ \\
\hline oykjamyrtjorn & pollen & temp & $\circ$ & temp & air & July & WAPLS & positive & $\mathrm{X}$ \\
\hline oykjamyrtjorn & chironomids & temp & $\circ$ & temp & air & July & WAPLS & positive & $\mathrm{X}$ \\
\hline raigastvere & pollen & temp & $\circ$ & temp & air & annual & WAPLS & positive & $\mathrm{X}$ \\
\hline ratasjoen & chironomids & temp & $\circ$ & temp & air & July & WAPLS & positive & $\mathrm{X}$ \\
\hline reiarsdalsvatnet & pollen & temp & $\circ$ & temp & air & July & WAPLS & positive & $\mathrm{X}$ \\
\hline ruila & pollen & temp & $\circ$ & temp & air & annual & WAPLS & positive & $\mathrm{X}$ \\
\hline rystad & humification_index & humification_index & $\%$ & moisutre & eff & annual & mean & negative & \\
\hline saarikko & $\mathrm{d}^{18} \mathrm{O}$.cell & $\mathrm{d}^{18} \mathrm{O}$ & permil & moisture & eff & annual & mean & negative & \\
\hline sellevollmyra & humification_index & humification_index & $\%$ & moisture & eff & annual & mean & negative & \\
\hline sjuuodjijaure & pollen & temp & $\circ$ & temp & air & July & WAPLS & positive & $\mathrm{X}$ \\
\hline sjuuodjijaure & chironomids & temp & $\circ$ & temp & air & July & WAPLS & positive & $\mathrm{X}$ \\
\hline sjuuodjijaure & diatoms & temp & $\circ$ & temp & air & July & WAPLS & positive & $\mathrm{X}$ \\
\hline soylegrotta & $d^{18} \mathrm{O}$ & temp & $\circ$ & temp & air & annual & SDF & positive & $\mathrm{X}$ \\
\hline spaime & $\mathrm{d}^{18}$ O.cellulose & $\mathrm{d}^{18} \mathrm{O}$ & permil.smow & mode & NAO & winter & none & positive & \\
\hline spaime & chironomids & temp & & temp & air & July & WAPLS & positive & $\mathrm{X}$ \\
\hline Stomyren & humification_index & humification_index & abs & moisture & eff & annual & mean & negative & \\
\hline svanavatnet & pollen & precip & $\mathrm{mm}$ & precip & rain + snow & annual & WAPLS & positive & $\mathrm{X}$ \\
\hline svanavatnet & pollen & temp & $\circ$ & temp & air & January & WAPLS & positive & $\mathrm{X}$ \\
\hline svanavatnet & pollen & temp & $\circ$ & temp & air & July & WAPLS & positive & $\mathrm{X}$ \\
\hline svartkalstjarn & $\mathrm{d}^{18} \mathrm{O}$ & $\mathrm{d}^{18} \mathrm{O}$ & permil.smow & precip & rain + snow & winter & sum & positive & \\
\hline svartvatnet & pollen & temp & $\circ$ & temp & air & July & WAPLS & positive & $\mathrm{X}$ \\
\hline tiavatnet & pollen & temp & $\circ$ & temp & air & July & WAPLS & positive & $X$ \\
\hline tibetanus & $\mathrm{d}^{18} \mathrm{O}$ & $\mathrm{d}^{18} \mathrm{O}$ & permil.pdb & mode & & & & positive & \\
\hline tibetanus & pollen & precip & $\mathrm{mm}$ & precip & rain + snow & annual & WAPLS & positive & $\mathrm{X}$ \\
\hline tibetanus & pollen & temp & $\circ$ & temp & air & July & WAPLS & positive & $\mathrm{X}$ \\
\hline tornetrask & width & temp & $\circ$ & temp & air & JJA & mean & positive & $X$ \\
\hline toskaljavri & pollen & precip & $\mathrm{mm}$ & precip & rain + snow & annual & WAPLS & positive & $\mathrm{X}$ \\
\hline toskaljavri & pollen & temp & $\circ$ & temp & air & July & WAPLS & positive & $\mathrm{X}$ \\
\hline toskaljavri & chironomids & temp & $\circ$ & temp & air & July & WAPLS & positive & $\mathrm{X}$ \\
\hline trehorningen & pollen & temp & $\circ$ & temp & air & annual & WAPLS & positive & $\mathrm{X}$ \\
\hline trettetjorn & pollen & temp & $\circ$ & temp & air & July & WAPLS & positive & $\mathrm{X}$ \\
\hline tsuolbmajavri & pollen & precip & $\mathrm{mm}$ & precip & rain + snow & annual & WAPLS & positive & $\mathrm{X}$ \\
\hline tsuolbmajavri & diatoms & temp & $\circ$ & temp & air & July & WAPLS & positive & $\mathrm{X}$ \\
\hline
\end{tabular}


Table 2. Continued.

\begin{tabular}{|c|c|c|c|c|c|c|c|c|c|}
\hline tsuolbmajavri & chironomids & temp & $\circ$ & temp & air & July & WAPLS & positive & $\mathrm{X}$ \\
\hline vikjordvatnet & OM.flux & OM_flux & $\mathrm{g} \mathrm{cm}^{-2}$ year $^{-1}$ & temp & air & annual & mean & positive & \\
\hline vuoskkujavri & pollen & precip & $\mathrm{mm}$ & precip & rain + snow & annual & WAPLS & positive & $\mathrm{X}$ \\
\hline vuoskkujavri & pollen & temp & $\circ$ & temp & air & January & WAPLS & positive & $\mathrm{X}$ \\
\hline vuoskkujavri & chironomids & temp & $\circ$ & temp & air & July & WAPLS & positive & $\mathrm{X}$ \\
\hline vuoskkujavri & diatoms & temp & $\circ$ & temp & air & July & WAPLS & positive & $\mathrm{X}$ \\
\hline vuoskkujavri & pollen & temp & $\circ$ & temp & air & July & WAPLS & positive & $\mathrm{X}$ \\
\hline yarnyshnoe & pollen & temp & $\circ$ & temp & air & July & WAPLS & positive & $\mathrm{X}$ \\
\hline \multicolumn{10}{|c|}{ Mainland Canada } \\
\hline $2005-804$ & dinocysts & sea_ice_months & months year $^{-1}$ & ice & sea & annual & MAT & positive & $\mathrm{X}$ \\
\hline $2005-804$ & dinocysts & sea_ice_conc & $0-10$ & ice & sea & annual & MAT & positive & $\mathrm{X}$ \\
\hline $2005-804$ & dinocysts & salinity & psu & salinity & sea_surface & summer & MAT & positive & $\mathrm{X}$ \\
\hline $2005-804$ & dinocysts & salinity & psu & salinity & sea_surface & winter & MAT & positive & $\mathrm{X}$ \\
\hline $2005-804$ & dinocysts & temp & $\circ$ & temp & sea_surface & summer & MAT & positive & $\mathrm{X}$ \\
\hline $2005-804$ & dinocysts & temp & $\circ$ & temp & sea_surface & winter & MAT & positive & $\mathrm{X}$ \\
\hline $\mathrm{ARC} 4$ & IP25 & IP25_flux & $\mu \mathrm{g} \mathrm{cm}^{-2}$ year $^{-1}$ & ice & sea $^{-}$ & spring & occurrence & positive & \\
\hline ARC5 & IP25 & IP25_flux & $\mu \mathrm{g} \mathrm{cm}^{-2}$ year $^{-1}$ & ice & sea & spring & occurrence & positive & \\
\hline ennadai & pollen & precip & $\mathrm{mm}$ & precip & rain + snow & annual & MAT & positive & $\mathrm{X}$ \\
\hline ennadai & pollen & temp & $\circ$ & temp & air & coldest & MAT & positive & $\mathrm{X}$ \\
\hline ennadai & pollen & temp & $\circ$ & temp & air & warmest & MAT & positive & $\mathrm{X}$ \\
\hline JR01 & pollen & temp & $\circ$ & temp & air & July & MAT & positive & $\mathrm{X}$ \\
\hline $\mathrm{k} 2$ & $\begin{array}{l}\text { pollen,chironomids, } \\
\text { diatoms }\end{array}$ & temp & $\circ$ & temp & air & July & WAPLS & positive & $\mathrm{X}$ \\
\hline KR02 & pollen & precip & $\mathrm{mm}$ & precip & rain + snow & annual & MAT & positive & $\mathrm{X}$ \\
\hline KR02 & pollen & precip & $\mathrm{mm}$ & precip & rain + snow & annual & PLS & positive & $\mathrm{X}$ \\
\hline KR02 & pollen & precip & $\mathrm{mm}$ & precip & rain + snow & annual & WAPLS & positive & $\mathrm{X}$ \\
\hline KR02 & pollen & temp & $\circ$ & temp & air & July & MAT & positive & $\mathrm{X}$ \\
\hline KR02 & pollen & temp & $\circ$ & temp & air & July & PLS & positive & $\mathrm{X}$ \\
\hline KR02 & pollen & temp & $\circ$ & temp & air & July & WAPLS & positive & $\mathrm{X}$ \\
\hline KR02 & $\mathrm{BSi}$ & $\mathrm{BSi}$ & $\%$ & temp & air & summer & mean & positive & \\
\hline LR01 & pollen & precip & $\mathrm{mm}$ & precip & rain + snow & annual & MAT & positive & $\mathrm{X}$ \\
\hline LR01 & pollen & temp & $\circ$ & temp & air & coldest & MAT & positive & $\mathrm{X}$ \\
\hline LR01 & pollen & temp & $\circ$ & temp & air & warmest & MAT & positive & $\mathrm{X}$ \\
\hline $\mathrm{s} 53 \mathrm{~s} 52$ & $\mathrm{~d}^{13} \mathrm{C}$. bulk_organics & temp & $\circ$ & temp & air & July & linear & positive & $\mathrm{X}$ \\
\hline toronto & $\mathrm{d}^{18}$ O.cellulose & $\mathrm{d}^{18} \mathrm{O}$ & permil.smow & precip & eff & annual & none & negative & \\
\hline & ARM/IRM & ARM/IRM & unitless & moisture & eff & annual & sum & positive & \\
\hline whatever & $\mathrm{d}^{18}$ O.cellulose & $\mathrm{d}^{18} \mathrm{O}$ & permil.smow & moisture & eff & annual & sum & negative & \\
\hline \multicolumn{10}{|c|}{ North Atlantic and Iceland } \\
\hline B997-321 & $\mathrm{d}^{18}$ O.forams & SST & $\circ$ & temp & near_surface & July & Bemise 1998 & positive & $\mathrm{X}$ \\
\hline GIK23258 & foraminifera.pl & SST & $\circ$ & temp & near_surface & summer & foram & positive & $\mathrm{X}$ \\
\hline haukdalsvatn & $\begin{array}{l}\mathrm{BSi}, \mathrm{d}^{13} \mathrm{C}, \mathrm{C}: \mathrm{N}, \mathrm{TOC}, \\
\text { MS,sed_acc_rate }\end{array}$ & $\mathrm{PC} 1$ & unitless & temp & air & summer & mean & positive & \\
\hline hvitarvatn & $\begin{array}{l}\text { BSi,d }{ }^{13} \mathrm{C}, \mathrm{C}: \mathrm{N}, \mathrm{TOC} \text {, } \\
\text { MS,sed_acc_rate }\end{array}$ & $\mathrm{PC} 1$ & unitless & temp & air & summer & mean & positive & \\
\hline JM01-1199 & foraminifera & SST & $\circ$ & temp & near_surface & summer & Est_ML & positive & $\mathrm{X}$ \\
\hline JM96-1207 & dinocysts & sea_ice_months & months year $^{-1}$ & ice & sea & annual & MAT & positive & $\mathrm{X}$ \\
\hline JM96-1207 & dinocysts & sea_ice_conc & $0-10$ & ice & sea & annual & MAT & positive & $\mathrm{X}$ \\
\hline JM96-1207 & dinocysts & salinity & psu & salinity & sea_surface & summer & MAT & positive & $\mathrm{X}$ \\
\hline JM96-1207 & dinocysts & salinity & psu & salinity & sea_surface & winter & MAT & positive & $\mathrm{X}$ \\
\hline JM96-1207 & dinocysts & temp & $\circ$ & temp & sea_surface & summer & MAT & positive & $\mathrm{X}$ \\
\hline JM96-1207 & dinocysts & temp & $\circ$ & temp & sea_surface & winter & MAT & positive & $\mathrm{X}$ \\
\hline JR51-GC35 & alkenones & SST & $\circ$ & temp & sea_surface & annual & mean & positive & $\mathrm{X}$ \\
\hline LO09 & diatoms & temp & $\circ$ & temp & sea_surface & August & WAPLS & positive & $\mathrm{X}$ \\
\hline malangen & foraminifera & SBT & $\circ$ & temp & bottomwater & annual & linear & positive & $\mathrm{X}$ \\
\hline MD95-2011 & foraminifera & SST & $\circ$ & temp & near_surface & August & WAPLS & positive & $\mathrm{X}$ \\
\hline MD95-2011 & diatoms & SST & $\circ$ & temp & sea_surface & annual & Prahl1987 & positive & $\mathrm{X}$ \\
\hline MD95-2011 & alkenones & SST & $\circ$ & temp & sea_surface & August & WAPLS & positive & $\mathrm{X}$ \\
\hline MD95-2015 & alkenones & SST & $\circ$ & temp & sea_surface & annual & Muller1998 & positive & $\mathrm{X}$ \\
\hline MD99-2256 & foraminifera & SBT & $\circ$ & temp & bottom water & annual & mean & positive & $\mathrm{X}$ \\
\hline MD99-2264 & foraminifera & SBT & $\circ$ & temp & bottom water & annual & mean & positive & $\mathrm{X}$ \\
\hline MD99-2269 & diatoms & SST & $\circ$ & temp & sea_surface & August & WAPLS & positive & $\mathrm{X}$ \\
\hline MD99-2317 & $\mathrm{d}^{18}$ O.forams & $\mathrm{d}^{18} \mathrm{O}$ & permil & temp & near_surface & & & negative & \\
\hline MD99-2322 & foraminifera & temp & o & temp & near_surface & & & positive & $\mathrm{X}$ \\
\hline MD99-2322 & $\mathrm{d}^{18} \mathrm{O}$.forams & $d^{18} \mathrm{O}$ & permil & temp & near_surface & & & negative & \\
\hline mjauvotn & XRF, $\mathrm{d}^{13} \mathrm{C}, \mathrm{C}, \mathrm{N}, \mathrm{S}, \mathrm{MS}$ & $\mathrm{PC} 1$ & unitless & temp\&precip & air\&rain + snow & annual & mean & positive & \\
\hline MSM05-712 & IP25 & IP25_flux & $\mu \mathrm{g} \mathrm{cm}^{-2}$ year $^{-1}$ & ice & sea & & & positive & \\
\hline MSM05-712 & dinocysts & salinity & psu & ice & sea & annual & MAT & positive & $\mathrm{X}$ \\
\hline MSM05-712 & dinocysts & sea_ice_months & months year $^{-1}$ & ice & sea & annual & MAT & positive & $\mathrm{X}$ \\
\hline MSM05-712 & dinocysts & temp & $\circ$ & salinity & sea_surface & summer & MAT & positive & $\mathrm{X}$ \\
\hline MSM05-712 & dinocysts & temp & $\circ$ & salinity & sea_surface & winter & MAT & positive & $\mathrm{X}$ \\
\hline MSM05-712 & dinocysts & salinity & psu & temp & sea_surface & summer & MAT & positive & $\mathrm{X}$ \\
\hline MSM05-723 & IP25 & IP25_flux & $\mu \mathrm{g} \mathrm{cm}^{-2}$ year $^{-1}$ & ice & sea & & & positive & \\
\hline ODP-684 & $\mathrm{Mg} / \mathrm{Ca}$ & temp & & temp & near_surface & summer & Langen 2005 & positive & $\mathrm{X}$ \\
\hline P1003 & forams & $\mathrm{d}^{18} \mathrm{O}$ & permil & temp & near_surface & & & negative & \\
\hline PS2641 & IP25 & IP25_flux & $\mu \mathrm{g} \mathrm{cm}^{-2}$ year $^{-1}$ & ice & sea & & & positive & \\
\hline RAPID-12 & $\mathrm{Mg} / \mathrm{Ca}$ & SST & & temp & near_surface & & & positive & $\mathrm{X}$ \\
\hline starvatn & grain_size & grain_flux & grains $>255 \mu \mathrm{m} \mathrm{cm}^{-3}$ & temp (+wind $)$ & air & winter & & positive & \\
\hline starvatn & $\mathrm{BSi}$ & $\mathrm{BSi}$ & $\%$ & temp & air & summer & & negative & \\
\hline Troll28-03 & foraminifera & SST & $\circ$ & temp & near_surface & & WAPLS & positive & $\mathrm{X}$ \\
\hline Troll28-03 & foraminifera & SST & $\circ$ & temp & near_surface & JJA & WAPLS & positive & $\mathrm{X}$ \\
\hline
\end{tabular}


Table 2. Continued.

\begin{tabular}{|c|c|c|c|c|c|c|c|c|c|}
\hline \multicolumn{10}{|c|}{ Russian Arctic } \\
\hline dolgoe & pollen & precip & $\mathrm{mm}$ & precip & rain + snow & annual & & positive & $\mathrm{X}$ \\
\hline dolgoe & not_climate_related & $\mathrm{d}^{18} \mathrm{O}$ & permil & moisture_effective & rain + snow & annual & sum & negative & \\
\hline dolgoe & pollen & temp & $\circ$ & temp & air & July & mean & positive & $\mathrm{X}$ \\
\hline kharinei & chironomids & temp & $\circ$ & temp & air & July & WAPLS & positive & $\mathrm{X}$ \\
\hline kharinei & pollen & temp & $\circ$ & temp & air & MJJA & WAPLS & positive & $\mathrm{X}$ \\
\hline lyadhej-To & pollen,chironomids, diatoms & temp & $\circ$ & temp & air & July & WAPLS & positive & $\mathrm{X}$ \\
\hline PL-96 & dinocysts & sea_ice_months & months year $^{-1}$ & ice & sea & annual & MAT & positive & $\mathrm{X}$ \\
\hline PL-96 & dinocysts & sea_ice_conc & $0-10$ & ice & sea & annual & MAT & positive & $\mathrm{X}$ \\
\hline PL-96 & dinocysts & salinity & psu & salinity & sea_surface & summer & MAT & positive & $\mathrm{X}$ \\
\hline PL-96 & dinocysts & salinity & psu & salinity & sea_surface & winter & MAT & positive & $\mathrm{X}$ \\
\hline PL-96 & dinocysts & temp & $\circ$ & temp & sea_surface & summer & MAT & positive & $\mathrm{X}$ \\
\hline PL-96 & dinocysts & temp & $\circ$ & temp & sea_surface & winter & MAT & positive & $\mathrm{X}$ \\
\hline sysy-kyuele & diatoms & diatom_concentration & $1000 \times$ valves $\mathrm{g}^{-1}$ & temp & lake_surface & summer & mean & positive & \\
\hline
\end{tabular}

can also act as a depository for terrestrial-based proxies, such as pollen from arboreal trees or the accumulation of rock flour from glacier runoff that do not reflect changes within the aquatic system. Multiproxy indicators from both aquatic and terrestrial sources provide independent lines of evidence that can corroborate shifts in Holocene climate.

Chironomids. Chironomids (Diptera: Chironomidae non-biting midges) spend part of their life cycle in the bottom waters of lakes. Summer temperature is an important driver of chironomid species distributions, and the utility of chironomid larval remains for palaeotemperature reconstructions is well established (e.g. Walker, 2001; MacDonald et al., 2009; Eggermont and Heiri, 2012; Brooks et al., 2012). Chironomids are abundant and well preserved in many Arctic lakes, and calibrated chironomid temperature transfer functions have been developed for multiple Arctic regions (e.g. Barley et al., 2006; Brooks and Birks, 2001; Francis et al., 2006). Twenty-five records in this database rely on chironomid species assemblages to develop quantitative mean July air temperature records.

Diatoms. Diatoms (siliceous algae) are commonly studied in Arctic ponds and lakes because they respond quickly and sensitively, although indirectly, to climate change. In Arctic freshwater systems, ice and snow cover are important ecological factors that influence diatom assemblages and are mediated by climate (e.g. temperature, wind, cloud cover; Douglas and Smol, 2010). For example, a warmer climate and longer open-water period can result in a shift towards a more species-rich assemblage as new diatom habitats become available and, in deeper lakes, can also result in a change in diatom life strategy from mostly benthic to more planktonic assemblages with increased thermal stability and reduced mixing strength (Smol et al., 2005; Rühland et al., 2008). Diatoms have also been successfully used to track Arctic Holocene tree-line migration through diatom-inferred changes in dissolved organic carbon (DOC) (Rouillard et al., 2011, 2012). For example, warmer temperatures during the Holocene thermal maximum followed by a return to cooler conditions during the Neoglacial, led to the advancement (and then retreat) of needle-leaf trees onto (and from) the catchments of tundra lakes for the first time, thereby increas- ing (and then decreasing) DOC delivery to the lake (Pienitz et al., 1999).

Pollen. The quantitative reconstruction of a large variety of climate variables has a long history, pioneered by Webb and Bryson (1972), and has been widely applied in the Arctic (e.g. Sawada et al., 1999; Seppä and Birks, 2002; Kerwin et al., 2004; Seppä et al., 2008) and beyond, primarily to reconstruct various parameters relating to temperature and precipitation. The influence of climate on the distribution of plant species and vegetation composition is particularly strong near the distribution limits of plants and in the regions with strong climatic gradients. For example, the position of the Arctic tree line is predominantly controlled by summer warmth and growing season length (Grace et al., 2002; Harsch et al., 2009) and past tree line shifts reflect summer temperature changes. In the Arctic, there are also significant annual or subdecadal variations in the pollen values, caused by the pollen productivity response to short-term (annual) summer temperature variability (Barnekow et al., 2007; Kuoppamaa et al., 2009).

Production indicators. Longer growing seasons at high latitudes as a result of reduced ice-cover duration have often been associated with increased primary production in freshwater and marine systems. Biogenic-silica (BSi) content of lake sediment can be used to infer changes in diatom and chrysophyte abundance, which often account for large portions of aquatic primary production and can be analysed at high resolution (millimetre scale, decadal resolution). For high-latitude lakes, temperature, wind and cloud cover are the major controls for the duration of the ice-free season (Hobbie, 1984; Sagarin and Micheli, 2001), which influences diatom production (e.g. Smol, 1988; Smol and Douglas, 2007) and thus BSi content. Climate-mediated changes in lacustrine aquatic primary production can also be estimated through visible reflectance spectroscopy that enables quantitative inferences of sedimentary chlorophyll $a$, including primary chlorophyll $a$ and all its isomers and phaeopigments (Michelutti et al., 2005, 2010).

Stable isotopes. A growing number of studies have demonstrated the utility of the oxygen $\left(\delta^{18} \mathrm{O}\right)$ and hydrogen $(\delta \mathrm{D})$ isotopic ratio of organic material and carbonates preserved 
in lake sediment for reconstructing hydroclimatic changes. Although interpreting the isotopic signal from lake sediment is often complicated because isotope fractionation is also influenced by other factors such as temperature (Leng and Marshall, 2004), the interpretation of downcore trends can be guided by comparing the isotopic records with values analysed from modern lake water and precipitation in the study area. Most $\delta^{18} \mathrm{O}$-based lake reconstructions use carbonates associated with calcifying Chara algae, but some are based on ostracodes and siliceous diatoms. $\delta$ D-based reconstructions use leaf wax biomarkers, which can reflect the isotopic composition of growth water, local precipitation or lake water used by a plant after modification by evaporation and biosynthetic fractionation (Sachse et al., 2012).

\subsubsection{Marine sediments}

The records from marine sediment account for $32 \%$ (103), nearly all from the North Atlantic. Of the 27 marine sites included, 11 are represented by time series for more than one proxy type. Most of these relate to changes in sea surface temperature (SST) or subsurface temperature. Some provide additional information on sea-ice cover occurrence and concentration.

Diatoms, dinoflagellates and haptophyte algae that relate to phytoplanktic productivity in the photic zone provide information on the properties of the upper water layer and SST. When opal silica is preserved in sediment, diatom assemblages can be used as a proxy for SST (Koç et al., 1993). Some diatom species are associated with spring sea ice and produce organic biomarkers $\left(\mathrm{IP}_{25}\right)$ that are used as tracers of seasonal sea-ice occurrence (Belt and Müller, 2013). The ratio of unsaturations in alkenones derived from haptophyte algae $\left(U_{37}^{K^{\prime}}\right)$ is dependent upon the temperature and can be used to estimate SST, although the occurrence of four double bonds, which is frequent in polar and subpolar environments, may obscure the temperature signal (Rosell-Mélé and McClymont, 2007). Organic-walled dinoflagellate cysts (or dinocysts) resulting from sexual reproduction are usually well preserved in sediment. The distribution of species depends mostly upon the seasonal cycle of temperature and the extent of sea-ice cover. Large databases of modern species distributions covering the Northern Hemisphere have enabled MAT reconstructions of sea-surface parameters including SST, salinity and sea-ice cover concentration (de Vernal and Marret, 2007; de Vernal et al., 2001, 2013).

Planktic foraminifera, which are heterotrophic and stenohaline, often inhabit subsurface waters, especially in polar environments marked by strong stratification of the upper water column (e.g. Kucera, 2007). Hence, $\delta^{18} \mathrm{O}$ values and $\mathrm{Mg} / \mathrm{Ca}$ values of their shells relate to the properties of sea water at the calcification depth and provide information on subsurface temperature and water mass stratification.
In temperate to subarctic oceanic environments, planktonic foraminifera may be used for SST estimates based on transfer functions or MAT (Kucera et al., 2005).

Benthic organisms including foraminifera and ostracods (e.g. Jennings et al., 2004; Sejrup et al., 2004b; Olafsdottir et al., 2010) can also be used to qualitatively reconstruct temperatures at the bottom of the ocean, but their interpretation is rarely unequivocal (Seidenkrantz, 2013).

\subsubsection{Glacier ice}

The database includes 10 ice-core records from Greenland and ice caps in the Canadian Arctic. Geochemical properties such as $\delta^{18} \mathrm{O}$ provide information on the isotopic composition of precipitation, air temperature, and atmospheric circulation at the time of formation, whereas annual layer thickness and structure can provide information on precipitation accumulation rate and annual melting of ice. Annual layer counting provides tight geochronological control that approaches annual resolution. In the recent decade, the timescales for the Greenland ice core records have been reconciled using the GIC05 (Greenland Ice Core version 5) chronology (Vinther et al., 2008). Canadian ice cores, including the Agassiz ice core, adopt the ages of prominent volcanic acid layers from GIC05 for chronological control.

\subsubsection{Speleothems}

Speleothems are formed when calcium carbonate precipitates from ground water seeping into limestone caves (Fairchild and Baker, 2012). Stable oxygen and carbon isotopes, trace elements and width of annual lamina are all influenced by surface conditions (e.g. McDermot et al., 2004, 2010; Fairchild et al., 2006) and can be used to infer past changes in temperature, hydroclimate, and vegetation. The database includes only two speleothem records, both from northern Norway (Lauritzen and Lundberg, 1999; Linge et al., 2009). From this area, a negative relation between temperature and $\delta^{18} \mathrm{O}$ has been inferred.

\subsubsection{Peat}

Vast peatlands have developed in northern North America and Eurasia since the last glaciation and much of the world's peatlands are in subarctic and boreal regions of Canada, Siberia, Fennoscandia and Alaska. Climate changes can be reconstructed from the degree of peat humification as an indicator of dry/wet mire surface conditions, and from stable isotopes in peat mosses. Proxy records from peat deposits can often provide a higher temporal resolution than sediment records from Arctic lakes and ponds (e.g. Brown et al., 1994; Gaiser and Rühland, 2010). The database includes peat records from five sites: four based on humification indices from Fennoscandia (Borgmark and Wastegård, 2008; Vorren et al., 2007, 2012) and one based on $\delta^{13} \mathrm{C}$ from the Canadian mainland (Tillman et al., 2010). 


\subsubsection{Tree rings}

Tree rings can provide information about past temperatures or moisture, based on measurements of ring widths or maximum latewood density (Jones et al., 2009). Only a few treering records that extend to $6 \mathrm{ka}$ are available from the Arctic (e.g. Grudd et al., 2002; Helama et al., 2010), all of which are interpreted as records of summer temperature. Using the approach of individual standardization of each tree-ring record, the maximum wavelength of recoverable climatic information is a function of the lengths of the individual tree-ring series and therefore tree-ring width does not express the full range of millennial timescale temperature variation (e.g. Linderholm et al., 2010; Helama et al., 2012).

\subsection{Climate variables}

The majority (56\%) of the proxy records in the database have been transformed or calibrated to a specific climate variable. These are based on microfossil assemblages, treering widths, and stable-isotope composition. Most (>90\%) of the calibrated records in the database use transfer functions or MAT to infer temperature from biological remains. The uncertainties that have been estimated for the reconstructions vary with differences in statistical methods and in calibration data sets; e.g. for pollen-based reconstructions, reported uncertainties range from $0.2^{\circ} \mathrm{C}$ (Kerwin et al., 2004) to $2.5^{\circ} \mathrm{C}$ (Andreev et al., 2005). The largest calibration uncertainties are associated with pollen reconstructions of winter temperature and the smallest are for the pollen reconstructions of summer or annual temperature, and reconstructions based on diatom assemblages. Pollen assemblages are generally highly correlated with summer temperature in areas with a short growing season, or with annual temperature in areas with a longer growing season (e.g. Seppä et al., 2009). Generally, calibration and other uncertainties are large relative to the small amplitude of most Holocene climate change. The original data sources (cited here for each study) characterize the unique uncertainties associated with each reconstruction. The remaining proxy records indirectly track changes in climate variables and the relation between the proxy and climate variables for these uncalibrated proxies may not be linear.

\subsubsection{Temperature}

The database includes 116 records of reconstructed terrestrial summer temperature, with an additional 25 records that represent mean annual temperatures and 15 for mean winter temperature. From the marine sites there are four reconstructions of SST and four of bottom-water temperature.

\subsubsection{Moisture}

Moisture proxies include properties that have been interpreted in terms of the amount of precipitation, effective mois-

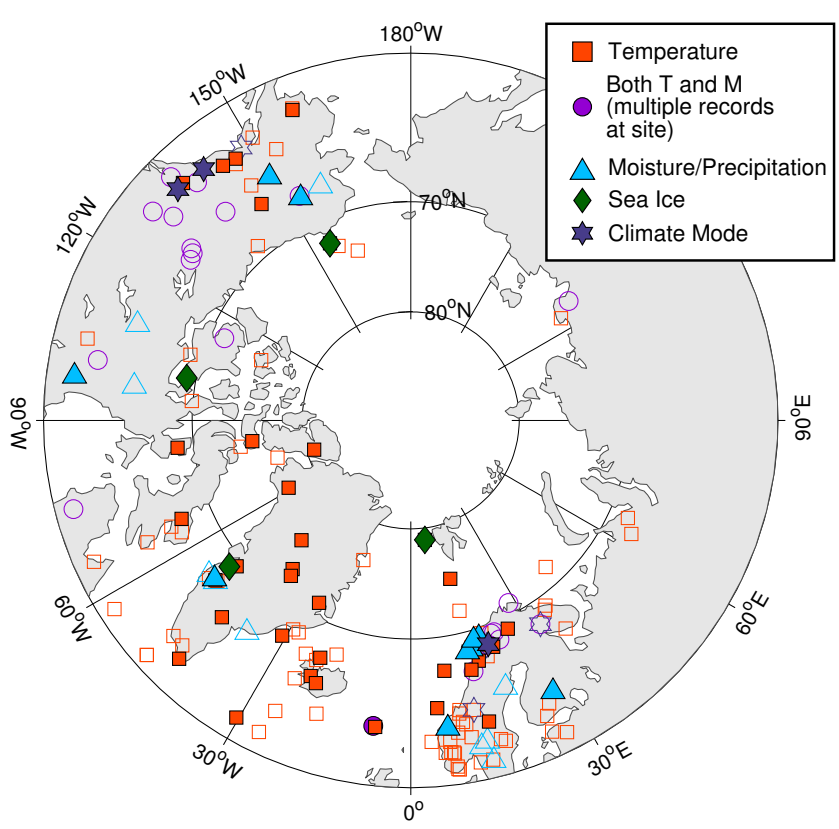

Figure 4. Location of proxy records in the database with sampling resolution $<100$ years and geochronology accuracy score $>0$ (solid symbols) relative to other records (open symbols) plotted by climate variable ( $T$ and $M$ : temperature and moisture variables of all types, respectively).

ture (precipitation minus evapotranspiration), lake levels, bog-surface wetness, or drought. They relate to hydroclimate variability. The database includes 48 moisture records. Quantitative estimates of precipitation are available only from pollen records and glaciolacustrine sediments.

\subsubsection{Glacier extent}

The equilibrium-line altitude (ELA) of glaciers is controlled by the effect of ablation-season (summer) temperature, which acts to reduce glacier mass (e.g. Koerner, 2005) and winter precipitation (which increases glacier mass). Glaciers advance and retreat in concert with persistent ELA change; glacier size influences the amount and grain-size distribution of sediments carried by meltwater streams. These changes can be detected as changes in the bulk density and organic-matter content of sediment in proglacial lakes (e.g. Bakke et al., 2005). The ELA records are all from western Norway and carry a strong winter signal as these glaciers are mainly controlled $(60-80 \%)$ by change in snow accumulation (Nesje and Matthews, 2012).

\subsubsection{Atmospheric circulation}

For high-latitude lakes not sensitive to evaporation, the $\delta^{18} \mathrm{O}$ of carbonates, diatoms, or cellulose can be used as a proxy for past changes in the $\delta^{18} \mathrm{O}$ of precipitation (Leng and Marshal, 2004; Jonsson et al., 2010). The $\delta^{18} \mathrm{O}$ of precipitation 
preserved in glacier ice from this region is generally used as a proxy for palaeotemperature (Vinther et al., 2010) but in some areas (e.g. Yukon) it is more sensitive to the watercycle history and can be used as a proxy for source region (e.g. Fisher et al., 2008). Because different air masses usually have distinct isotopic compositions, these records can give insights into past changes in atmospheric circulation. Oxygen isotope records have, for example, been used to reconstruct Holocene changes in the intensity and position of the Aleutian low-pressure system (Schiff et al., 2009) and the strength of the North Atlantic Oscillation (NAO) (e.g. Hammarlund et al., 2002). The database contains seven $\delta^{18} \mathrm{O}$ records interpreted to reflect atmospheric circulation.

\section{Concluding remarks}

Proxy climate records from the 170 sites that meet the criteria for this database form a network for investigating the spatio-temporal structure of Holocene climate changes in the Arctic, at least on submillennial timescales. On centennial timescales, the number of records with the appropriate resolution and geochronological control is more limited, but probably sufficient for discerning centennial-scale patterns in most regions (Figs. 3, 4). Overall, records from $44 \%$ of the sites across all regions have both an average resolution better than 100 years and a chron score higher than 0 (an arbitrary cutoff that includes $61 \%$ of the ${ }^{14} \mathrm{C}$-dated sites). In Fennoscandia, where the density of sites is highest, only $35 \%$ of the sites meet this standard, compared with $40-67 \%$ for the Canadian islands and Greenland, mainland Canada, and the North Atlantic and Iceland. In the Alaska and Yukon region, the distribution of resolutions is bimodal, subdivided between sites with pollen records versus nonpollen records. No proxy records meet this standard in the Russian Arctic. On decadal timescales, the number of records is presently too few to discern significant patterns, especially when considering limitations related to geochronology and proxy bias, which can include leads and lags relative to the climate forcing.
We suggest that this systematic review of the full range of marine and terrestrial proxy climate time series sets a new standard for Holocene proxy climate databases. It is based on quantitative screening criteria with new approaches for assessing the geochronological accuracy of age models and for characterizing the climate variables represented by the proxies. Records from only 67 of the 170 sites (39\%) included in this database were found in the primary palaeoclimate data repositories using the search criteria specified for this database, underscoring the important role of communitybased, expert-informed efforts to assembling a comprehensive product. The machine-readable database includes multiple parameters for searching and screening records that should enable new analyses of Holocene climate variability in the Arctic and identifying future research priorities. 


\section{Appendix A: Geochronology accuracy score}

The geochronology accuracy score (chron score) combines three indicators of the reliability of sediment-based age models, namely, the delineation $(D)$ of the downcore trend, the quality $(Q)$ of the dated samples, and the $(P)$ precision of the ${ }^{14} \mathrm{C}$ ages.

Delineation of downcore trend. The accuracy of an age model depends on how well the analysed samples delineate changes in sedimentation rate downcore. If the sedimentation rate is linear, then only two ages are needed to define it. With increasing variability of sedimentation rates, more ages are required to delineate accurately the downcore trend. In absence of stratigraphic information that attests to where within a sequence the sedimentation rate is most likely to have changed, evenly spaced samples increase the chances of capturing changes in sedimentation rate compared with the same number of ages clustered in small intervals. We therefore assess the extent to which an age model is accurately delineated by combining three attributes: (1) the frequency of ages, (2) the regularity of their spacing, and (3) the uniformity of the downcore trend.

The frequency of ages $(f)$ is quantified as the number of ages relative to the length of time represented by the sedimentary sequence, or

$f=\left(t_{\max }-t_{\min }\right) / n_{\text {tot }}$,

where $t_{\max }$ and $t_{\min }$ are the oldest and youngest ages, respectively, and $n_{\text {tot }}$ is the total number of ages that were accepted by the author of the age model. The age of the core surface is included if the sediment-water interface was captured at the time of coring.

The regularity $(r)$ of a series of ages is quantified by the standard deviation of the length of time that separates consecutive ages, or

$\left.r=\sigma_{[} t_{n}-t_{n+1}\right]$

where $\sigma$ is the standard deviation, and $t_{n}-t_{n+1}$ is the difference in time between the $n$th age and the next older age, as assessed for each age in a series. The absolute value is used for downcore age reversals.

The uniformity $(u)$ of the trend is quantified as the root mean standard error (RMSE) with respect to a cubic smoothing spline with a degree of freedom (d.f.) of 4 . If the spline fit contains a reversal, then the d.f. is lowered incrementally until there are no reversals in the spline fit.

The three attributes that make up the age-model $D$ can each be weighted to adjust their relative importance in the overall $D$ score:

$D=w_{f} f+w_{r} r+w_{u} u$

where $w_{f}, w_{r}$, and $w_{u}$ are weighting factors. Because the frequency of ages is fundamental to the accuracy of the age model, and because the RMSE is generally a low value, we chose to increase their weight in the overall score. Namely, we set the weighting factors of $2,0.5$, and 3 , respectively. The $D$ value increases with decreasing delineation.

Reliability of dated samples. The accuracy of age models generally depends on the type of material analysed, with some material types typically yielding ages that more closely represent the timing of deposition than others (e.g. Wolfe et al., 2004). In addition, the influence of contamination by young carbon, or the reworking of older material into younger sediment is often indicated by ages that violate stratigraphic superposition. We therefore assess the "quality" of dated materials based on two criteria: (1) the proportion of outliers and stratigraphically reversed ages, and (2) a qualitative (categorical) score based on the type of material dated.

Standard practice is to report the results of all radiocarbon analyses from a core or series of cores, then to identify and exclude the outliers if they exist. These analyses are indicated as rejected by the authors of the original age model. Minor age reversals are often retained in the age model, and the sedimentation-rate smoothing function is used to average the differences. In our scoring scheme, the proportion $(p)$ of outlier and stratigraphically reversed ages is the number of ages that were rejected by the original author, plus the number of stratigraphically reversed ages relative to the total number of dated samples, or

$p=1-\left(n_{\text {rej }}+n_{\text {rev }}\right) / n_{\text {tot }}$,

where $n_{\text {rej }}$ is the number of ages rejected by the original author and therefore not included in the list of ages used to calculate the $D$ score, $n_{\text {rev }}$ is the number of ages that are at least 100 years older than the next age downcore. The proportion is subtracted from 1 so that higher $p$ values signify a higher proportion of accepted and monotonically arranged ages.

We developed a fivefold classification scheme for the types of material $(\mathrm{m})$ used for the ${ }^{14} \mathrm{C}$ analyses. A value of $1-5$ is assigned to the entire series of samples, depending largely on the extent to which they comprise reliable types of sample material based on a specific set of criteria (see below). A value of 5 is reserved for age models that have been checked by independently derived ages from correlated tephra layers or ${ }^{14} \mathrm{C}$ wiggle matching. Separate classification schemes were developed for lacustrine and marine materials. $m$ values for lacustrine materials:

5: at least one age can be confirmed by tephra or ${ }^{14} \mathrm{C}$ wiggle matches; no bulk-sediment

4: mainly (>90\%) plant macrofossils

3: 50-90\% plant macrofossils; bulk-sediment ages can be reasonably adjusted

$2:<50 \%$ plant macrofossils

1: all bulk-sediment ages. 
$m$ values for marine materials:

5: $>90 \%$ whole, monospecific forams with a constrained reservoir age (at least one well-dated tephra or wiggle match used to determine the reservoir correction)

4: mainly (>90\%) monospecific forams

3: $>50 \%$ monospecific forams and articulated mollusks

2: mixture of sample types: fragmented and whole; monospecific and mixed species

1: mainly (>90\%) fragmented and unidentifiable tests and shells.

To derive a single value for $Q$ of the dated samples, we take the product of the two attributes, the proportion $(p)$ of accepted, monotonic ages, and the material $(m)$ type category, or

$Q=p m$

$Q$ values increase with increasing sample quality.
Precision. All radiocarbon laboratories report the $\pm 1 \sigma$ analytical precision associated with the internal reproducibility of the counting statistics for ${ }^{14} \mathrm{C}$ ages. The analytical precision is controlled by the mass of carbon used for AMS (accelerator mass spectrometry) analysis, or the activity of the sample used for decay counting methods, and the length of time that the sample is analysed on the instrument. The extent to which the overall accuracy of an age model is influenced by the analytical precision is difficult to quantify. In general, analytical precision is on the order of decades, but the uncertainty is amplified when calibrated to calendar years. We developed a simple index for $P$, which is based on calibrated age ranges of the ${ }^{14} \mathrm{C}$ ages using the $\mathrm{IntCal04}$ calibration data set.

$P=s^{-1}$,

where $s$ is the mean $2 \sigma$ range of all calibrated ${ }^{14} \mathrm{C}$ ages. The inverse function is used to stratify the precision scores over the most precise end of the range (decadal scale) while de-emphasizing the differences among the less-precise ages (centennial scale). $P$ values increase with increasing precision.

Geochronology accuracy score. The overall score $(G$, chron score) is calculated by summing the weighted values of each of the three components:

$G=-w_{D} D+w_{Q} Q+w_{P} P$,

where $w_{D}, w_{Q}$, and $w_{P}$ are the weighting factors, which we set to $0.001,1$ and 200 , respectively, so that each component is of the same order of magnitude. 


\section{The Supplement related to this article is available online at doi:10.5194/cp-10-1605-2014-supplement.}

Author contribution. D. S. Kaufman led the project; H. S. Sundqvist and D. S. Kaufman wrote the manuscript; H. S. Sundqvist, D. S. Kaufman, N. L. Balascio and N. P. McKay designed the database and assembled and formatted the data; D. S. Kaufman and N. P. McKay developed the geochronology accuracy score, with assistance from A. E. Jennings and J. T. Andrews for categorizing marine material types; N. P. McKay developed the climate-variable interpretation scheme; J. P. Briner, L. C. Cwynar, H. P. Sejrup, H. Seppä and D. A. Subetto led the regional teams in their evaluations of all available proxy records; all co-authors helped identify and assemble the proxy data; all co-authors checked the accuracy and completeness of the database and contributed to manuscript preparation.

Acknowledgements. We thank the following for their valued input: A. Andreev, N. Bigelow, B. Fréchette, Á. Geirsdóttir, A. Henderson, F. S. Hu, K. Gibble, G. H. Miller, L. Syrykh, M. Wooller, $\mathrm{Z}$. Yu, and the many colleagues who kindly made digital versions of their data available for this product. D. Fisher and an anonymous reviewer provided helpful suggestions in the discussion phase of the manuscript. We are grateful to the IGBP - Past Global Changes (PAGES) International Project Office in Bern, Switzerland, for hosting D. S. Kaufman as a visiting scientist during the initial stages of this compilation, and for facilitating project meetings. This project was funded by NSF-ARC-1107869 and 0909332.

Edited by: B. Vinther

\section{References}

Adams, J. K. and Finkelstein, S. A.: Watershed-scale reconstruction of middle and late Holocene paleoenvironmental changes on Melville Peninsula, Nunavut, Canada, Quat. Sci. Rev., 29, 23022314, 2010.

Allen, J. R. M., Long, A. J., Ottley, C. J., Graham Pearson, D., and Huntley, B.: Holocene climate variability in northernmost Europe, Quat. Sci. Rev., 26, 1432-1453, 2007.

Alley, R. B.: The Younger Dryas cold interval as viewed from central Greenland, Quat. Sci. Rev., 19, 213-226, 2000.

Anderson, L., Abbott, M. B., Finney, B. P., and Burns, S. J.: Regional atmospheric circulation change in the North Pacific during the Holocene inferred from lacustrine carbonate oxygen isotopes, Yukon Territory, Canada, Quat. Res., 64, 21-35, 2005.

Anderson, N. J., Liversidge, A. C., McGowan, S., and Jones, M. D.: Lake and catchment response to Holocene environmental change: spatial variability along a climate gradient in southwest Greenland, J. Paleolimnol., 48, 209-222, 2012.

Andersson, C., Risebrobakken, B., Jansen, E., and Dahl, S. O.: Late Holocene surface ocean conditions of the Norwegian Sea (Vøring Plateau), Paleoceanogr., 18, 1044, doi:10.1029/2001PA000654, 2003.
Andreev, A. A., Tarasov, P. E., Ilyashuk, B. P., Ilyashuk, E. A., Cremer, H., Hermichen, W.-D., Wischer, F., and Hubberten, H.W.: Holocene environmental history recorded in Lake LyadhejTo sediments, Polar Urals, Russia, Palaeogeog., Palaeoclim., Palaeoecol., 223, 181-203, 2005.

Andresen, C. S., Björck, S., Bennike, O., and Bond, G.: Holocene climate changes in southern Greenland: evidence from lake sediments, J. Quat. Sci., 19, 783-795, 2004.

Andresen, C. S., Björck, S., Rundgren, M, Conley, D. J., and Jessen, C.: Rapid Holocene climate changes in the North Atlantic: evidence from lake sediments from the Faroe Islands, Boreas, 35, 23-34, 2006.

Antonsson, K. and Seppä, H.: Holocene temperatures in Bohuslän, southwest Sweden: a quantitative reconstruction from fossil pollen data, Boreas, 36, 400-410, 2007.

Antonsson, K., Brooks, S. J., Seppä, H., Telford, R. J., and Birks, H. J. B.: Quantitative palaeotemperature records inferred from fossil pollen and chironomid assemblages from Lake Gilltjärnen, northern central Sweden, J. Quat. Sci., 21, 831-841, 2006.

Axford, Y., Losee, S., Briner, J. P., Francis, D. R., Langdon, P. G., and Walker, I. R.: Holocene temperature history at the western Greenland Ice Sheet margin reconstructed from lake sediments, Quat. Sci. Rev., 59, 87-100, 2013.

Bakke, J., Lie, Ø., Nesje, A., Dahl, S. O., and Paasche, Ø.: Utilizing physical sediment variability in glacier-fed lakes for continuous glacier reconstructions during the Holocene, northern Folgefonna, western Norway, Holocene, 15, 161-176, 2005.

Bakke, J., Dahl, S. O., Paasche, Ø., Riis Simonsen, J., Kvisvik, B., Bakke, K., and Nesje, A.: A complete record of Holocene glacier variability at Austre Okstindbreen, northern Norway: an integrated approach, Quat. Sci. Rev., 29, 1246-1262, 2010.

Balascio, N. and Bradley, R.: Evaluating Holocene climate change in northern Norway using sediment records from two contrasting lake systems, J. Paleolimnol. 48, 259-273, 2012.

Balascio, N. L., D’Andrea, W. J., Bradley, R. S., and Perren, B. B.: Biogeochemical evidence for hydrologic changes during the Holocene in a lake sediment record from southeast Greenland, Holocene, 23, 1428-1439, 2013.

Barley, E. M., Walker, I. R., Kurek, J., Cwynar, L. C., Mathewes, R. W., Gajewski, K., and Finney, B.: A northwest North America training set: distribution of freshwater midges in relation to air temperature and lake depth, J. Paleolimnol., 36, 295-314, 2006.

Barnekow, L., Possnert, G., and Sandgren, P.: AMS ${ }^{14} \mathrm{C}$ chronologies of Holocene lake sediments in the Abisko area, northern Sweden - a comparison between dated bulk sediment and macrofossil samples, Geologiska Färeningens i Stockholm Förhandlingar (GFF), 120, 59-67, 1998.

Barnekow, L., Loader, N. J., Hicks, S., Froyd, C. A., and Goslar, T.: Strong correlation between summer temperature and pollen accumulation rates for Pinus sylvestris, Picea abies and Betula spp. in a high-resolution record from northern Sweden, J. Quat. Sci., 22, 653-658, 2007.

Bartlein, P. J., Harrison, S. P., Brewer, S., Connor, S., Davis, B. A. S., Gajewski, K., Guiot, J., Harrison-Prentice, T. I., Henderson, A. O., Peyron, A. H., Prentice, I. C., Scholze, M., Seppä, H., Shuman, B., Sugita, S., Thompson, R. S., Viau, A. E., Williams, J., and $\mathrm{Wu}, \mathrm{H}$.: Pollen-based continental climate reconstructions at 6 and $21 \mathrm{ka:}$ a global synthesis, Clim. Dynam., 37, 775-802, 2011. 
Belt, S. T. and Müller, J.: The Arctic sea ice biomarker IP25: a review of current understanding, recommendations for future research and applications in palaeo sea ice reconstructions, Quat. Sci. Rev., 79, 9-25, 2013.

Belt, S. T., Vare, L. L., Massé, G., Manners, H. R., Price, J. C., MacLachlan, S. E., Andrews, J. T., and Schmidt, S.: Striking similarities in temporal changes to spring sea ice occurrence across the central Canadian Arctic Archipelago over the last 7000 years, Quat. Sci. Rev. 29, 3489-3504, 2010.

Bender, M. M., Bryson, R. A., and Baerreis, D. A.: University of Wisconsin radiocarbon dates III, Radiocarbon, 9, 530-544, 1967.

Bendle, J. A. P. and Rosell-Melé, A.: High-resolution alkenone sea surface temperature variability on the North Icelandic Shelf: implications for Nordic Seas palaeoclimatic development during the Holocene, Holocene, 17, 9-24, 2007.

Berner, K. S., Koç, N., Divine, D., Godtliebsen, F., and Moros, M.: A decadal-scale Holocene sea surface temperature record from the subpolar North Atlantic constructed using diatoms and statistics and its relation to other climate parameters, Paleoceanogr., 23, PA2210, doi:10.1029/2006PA001339, 2008.

Berner, K. S., Koç, N., and Godtliebsen, F.: High frequency climate variability of the Norwegian Atlantic Current during the early Holocene period and a possible connection to the Gleissberg cycle, Holocene, 20, 245-255, 2010.

Bigelow, N. H., Linda, B., Brubaker, L. B., Mary, E., Edwards, M. E., Sandy, P., Harrison, S. P., Prentice, C. I., Anderson, P. M. Andreev, A. A., Bartlein, P. J., Christensen, T. R., Cramer, W., Kaplan, J. O., Lozhkin, A. V., Matveyeva, N. V., Murray, D. F., McGuire, A. D., Razzhivin, V. Y., Ritchie, J. C., Smith, B., Walker, D. A., Gajewski, K., Wolf, V., Holmqvist, B. H., Igarashi, Y., Kremenetskii, K., Aage, P., Pisaric, M. F. J., and Volkova, V. S.: Climate change and Arctic ecoystems: 1. Vegetation changes north of $55^{\circ} \mathrm{N}$ between the last glacial maximum, mid-Holocene, and present, J. Geophys. Res., 108, D198170, doi:10.1029/2002JD002558, 2003.

Bigler, C., Larocque, I., Peglar, S. M., Birks, H. J. B., and Hall, R. I.: Quantitative multiproxy assessment of long-term patterns of Holocene environmental change from a small lake near Abisko, northern Sweden, Holocene, 12, 481-496, 2002.

Bigler, C., Grahn, E., Larocque, I., Jeziorski, A., and Hall, R.: Holocene environmental change at Lake Njulla (999 ma.s.1.), northern Sweden: a comparison with four small nearby lakes alongan altitudinal gradient, J. Paleolimnol., 29, 13-29, 2003.

Bigler, C., Barnekow, L., Heinrichs, M., and Hall, R.: Holocene environmental history of Lake Vuolep Njakajaure (Abisko National Park, northern Sweden) reconstructed using biological proxy indicators, Veg. Hist. Archeobotany, 15, 309-320, 2006.

Birks, H. J. B., Heiri, O., Seppä, H., and Bjune, A. E.: Strengths and weaknesses of quantitative climate reconstructions based on late-Quaternary biological proxies, The Open Ecol. J., 3, 68-110, 2010.

Biskaborn, B. K., Herzschuh, U., Bolshiyanov, D., Savelieva, L., and Diekmann, B.: Environmental variability in northeastern Siberia during the last $\sim 13300$ years inferred from lake diatoms and sediment-geochemical parameters, Palaeogeog., Paleoclim., Palaeoecol., 329/330, 22-36, 2012.

Bjune, A. E., Birks, H. J. B., and Seppä, H.: Holocene vegetation and climate history on a continental-oceanic transect in northern
Fennoscandia based on pollen and plant macrofossils, Boreas, 33, 211-223, 2004.

Bjune, A. E. and Birks, H. J. B.: Holocene vegetation dynamics and inferred climate changes at Svanåvatnet, Mo i Rana, northern Norway, Boreas, 37, 146-156, 2008.

Bjune, A. E., Bakke, J., Nesje, A., and Birks, H. J. B.: Holocene mean July temperature and winter precipitation in western Norway inferred from palynological and glaciological lake-sediment proxies, Holocene, 15, 177-189, 2005.

Blois, J. L., Williams, J. W., Grimm, E. C., Jackson, S. T., and Graham, R. W.: A methodological framework for assessing and reducing temporal uncertainty in paleovegetation mapping from late-Quaternary pollen records, Quat. Sci. Rev., 30, 1926-1939, 2011.

Borgmark, A. and Wastegård, S.: Regional and local patterns of peat humification in three raised peat bogs in Värmland, southcentral Sweden, Geologiska Föreningens i Stockholm Förhandlingar (GFF), 130, 161-176, 2008.

Brooks, S. J. and Birks, H. J. B.: Chironomid-inferred air temperatures from late-glacial and Holocene sites in north-west Europe: Progress and problems, Quat. Sci. Rev., 20, 1723-1741, 2001.

Brooks, S. J.: Fossil midges (Diptera: Chironomidae) as palaeoclimatic indicators for the Eurasian region, Quat. Sci. Rev., 25, 1894-1910, 2006.

Brooks, S. J., Axford, Y., Heiri, O., Langdon, P. G., and LarocqueTobler, I.: Chironomids can be reliable proxies for Holocene temperatures, a comment on Velle et al. 2010, Holocene, 22, 14821494, 2012.

Brown, K. M., Douglas, M. S. V., and Smol, J. P.: Siliceous microfossils in a Holocene High Arctic peat deposit (Nordvest $\varnothing$, northern Greenland), Can. J. Bot., 72, 208-216, 1994.

Brubaker, L. B., Garfinkee, H. L., and Edwards, M. E.: A late Wisconsin and Holocene vegetation history from the central Brooks Range: implications for Alaskan palaeoecology, Quat. Res., 20, 194-214, 1983.

Bunbury, J. and Gajewski, K.: Postglacial climates inferred from a lake at treeline, southwest Yukon Territory, Canada, Special Theme: Modern Analogues in Quat. Sci. Rev., 28, 354-369, 2009.

CAPE Project Members: Holocene paleoclimate data from the Arctic: testing models of global climate change, Quat. Sci. Rev., 210, 1275-1287, 2001.

Calvo, E., Grimalt, J., and Jansen, E.: High resolution U37K sea surface temperature reconstruction in the Norwegian Sea during the Holocene, Quat. Sci. Rev., 21, 1385-1394, 2002.

Came, R. E., Oppo, D. W., and McManus, J. F.: Amplitude and timing of temperature and salinity variability in the subpolar North Atlantic over the past $10 \mathrm{kyr}$, Geology, 35, 315-318, 2007.

Camill, P., Umbanhowar, C., Jr., Geiss, C., Hobbs, W., Edlund, M., Shinneman, A., Dorale, J., and Lynch, J.: Holocene climate change and landscape development from a low-Arctic tundra lake in the western Hudson Bay region of Manitoba, Canada J. Paleolimnol., 48, 175-192, 2012.

Chakraborty, K., Finkelstein, S. A., Desloges, J. R., and Chow, N. A.: Holocene paleoenvironmental changes inferred from diatom assemblages in sediments of Kusawa Lake, Yukon Territory, Canada, Quat. Res., 74, 15-22, 2010. 
Clegg, B. F. and Hu, F. S.: An oxygen-isotope record of Holocene climate change in the south-central Brooks Range, Alaska, Quat. Sci. Rev., 29, 928-939, 2010.

Clegg, B. F., Clarke, G. H., Chipman, M. L., Chou, M., Walker, I. R., Tinner, W., and Hu, F. S.: Six millennia of summer temperature variation based on midge analysis of lake sediments from Alaska, Quat. Sci. Rev., 29, 3308-3316, 2010.

Clegg, B. F., Kelly, R., Clarke, G. H., Walker, I. R., and Hu, F. S.: Nonlinear response of summer temperature to Holocene insolation forcing in Alaska, P. Natl. Acad. Sci. USA, 108, 1929919304, 2011.

Cwynar, L. C.: A late Quaternary vegetation history from Lily Lake, Chilkat Peninsula, southeast Alaska, Can. J. Bot., 68, 11061112, 1990.

Cwynar, L. C. and Spear, R. W.: Reversion of forest to tundra in the central Yukon, Ecology, 72, 202-212, 1991.

D'Andrea, W. J., Huang, Y., Fritz, S. C., and Anderson, N. J.: Abrupt Holocene climate change as an important factor for human migration in West Greenland, P. Natl. Acad. Sci. USA, 108, 9765-9769, 2011.

Davis, P. T.: Holocene vegetation and climate record from Iglutalik Lake, Cumberland Sound, Baffin Island, Northwest Territories, Canada, Ph.D. Thesis, University of Colorado, Boulder, 1980.

de Vernal, A. and Hillaire-Marcel, C.: Provincialism in trends and high frequency changes in the northwest North Atlantic during the Holocene, Global Planet. Change, 54, 263-290, 2006.

de Vernal, A., Henry, M., Matthiessen, J., Mudie, P.J., Rochon, A., Boessenkool, K., Eynaud, F., Grøsfjeld, K., Guiot, J., Hamel, D. , Harland, R., Head, M.J., Kunz-Pirrung, M., Levac, E., Loucheur, V., Peyron, O., Pospelova, V., Radi, T., Turon, J.-L., and Voronina, E.: Dinoflagellate cyst assemblages as tracers of sea-surface conditions in the northern North Atlantic, Arctic and sub-Arctic seas: the new ' $n=677$ ' database and application for quantitative paleoceanographical reconstruction, J. Quat. Sci., 16, 681-699, 2001.

de Vernal, A., Hillaire-Marcel, C., and Darby, D.: Variability of sea ice cover in the Chukchi Sea (western Arctic Ocean) during the Holocene, Paleoceanogr., 20, PA4018, doi:10.1029/2005PA001157, 2005.

de Vernal, A., Hillaire-Marcel, C., Rochon, A., Fréchette, B., Henry, M., Solignac, S., and Bonnet, S.: Dinocyst-based reconstructions of sea ice cover concentration during the Holocene in the Arctic Ocean, the northern North Atlantic Ocean and its adjacent seas, Quat. Sci. Rev., 79, 111-121, 2013.

Douglas, M. S. V. and Smol, J. P.: Freshwater diatoms as indicators of environmental change in the High Arctic, in: The Diatoms: Applications for the Environmental and Earth Sciences, 2nd Edn., edited by: Smol, J. P. and Stoermer, E. F., Cambridge University Press, 249-266, 2010.

Eggermont, H. and Heiri, O.: The chironomid-temperature relationship: expressions in nature and palaeoenvironmental implications, Biol. Rev., 87, 430-456, 2012.

Eide, W., Birks, H., Bigelow, N., Peglar, S., and Birks, H. J.: Holocene forest development along the Setesdal valley, southern Norway, reconstructed from macrofossil and pollen evidence, Veg. Hist. Archaeobotany, 15, 65-85, 2006.

Emile-Geay, J. and Eshleman, J. A.: Toward a semantic web of paleoclimatology. Geochem. Geophys. Geosyst., 14, 457-469, doi:10.1002/ggge.20067, 2013.
Fairchild, I. J., Smith, C. L., Baker, A., Fuller, L., Spötl, C., Mattey, D., and McDermott, F.: Modification and preservation of environmental signals in speleothems, Earth-Sci. Rev., 75, 105-153, 2006.

Fairchild, I. J. and Baker, A.: Speleothem Science: From Process to Past Environments, Wiley-Blackwell, 416 pp., 2012.

Fallu, M.-A., Pienitz, R., Walker, I. R., and Lavoie, M.: Paleolimnology of a shrub-tundra lake and response of aquatic and terrestrial indicators to climatic change in arctic Québec, Canada, Palaeogeogr. Palaeoecol., 215, 183-203, 2005.

Farmer, J. R., Cronin, T. M., de Vernal, A., Dwyer, G. S., Keigwin, L. D., and Thunell, R. C.: Western Arctic Ocean temperature variability during the last 8000 years, Geophys. Res. Lett., 38, L24602, doi:10.1029/2011GL049714, 2011.

Finney, B., Bigelow, N., Barber, V., and Edwards, M.: Holocene climate change and carbon cycling in a groundwater-fed, boreal forest lake: Dune Lake, Alaska, J. Paleolimnol., 48, 43-54, 2012.

Fisher, D., Osterberg, E., Dyke, A., Dahl-Jensen, D., Demuth, M., Zdanowicz, C., Bourgeois, J., Koerner, R. M., Mayewski, P., Wake, C., Kreutz, K., Steig, E., Zheng, J., Yalcin, K., GotoAzuma, K., Luckman, B., and Rupper, S.: The Mt Logan Holocene - late Wisconsinan isotope record: tropical Pacific Yukon connections, Holocene, 18, 667-677, 2008.

Fisher, D. A.: High-resolution multiproxy climate records from ice cores, tree rings, corals and documentary sources using eigenvector techniques and maps: assessment of recovered signal and errors, Holocene, 12, 323-340, 2002.

Fisher, D. A., Koerner, R. M., Paterson, W. S. B., Dansgaard, W., Gundestrup, N., and Reeh, N.: Effect of wind scouring on climatic records from ice-core oxygen-isotope profiles, Nature, 301, 205-209, 1983.

Fisher, D. A., Koerner, R. M., Bourgeois, J. C., Zielinski, G., Wake, C., Hammer, C. U., Clausen, H. B., Gundestrup, N., Johnsen, S., Goto-Azuma, K., Hondoh, T., Blake, E., and Gerasimoff, M.: Penny Ice Cap cores, Baffin Island, Canada, and the Wisconsinan Foxe Dome connection: Two states of Hudson Bay ice cover, Science, 279, 692-695, 1998.

Francis, D. R., Wolfe, A. P., Walker, I. R., and Miller, G. H.: Interglacial and Holocene temperature reconstructions based on midge remains in sediments of two lakes from Baffin Island, Nunavut, Arctic Canada, Palaeogeogr., Palaeoclim., Palaeoecol., 236, 107-124, 2006.

Fréchette, B. and de Vernal, A., Relationship between Holocene climate variations over southern Greenland and eastern Baffin Island and synoptic circulation pattern. Clim. Past, 5, 347-359, 2009 , http://www.clim-past.net/5/347/2009/.

Gaiser, E. and Rühland, K.: Diatoms as indicators of environmental change in wetlands and peatlands, in: The Diatoms: Applications for the Environmental and Earth Sciences, 2nd Edn., edited by: Smol, J. P. and Stoermer, E. F., Cambridge University Press, Cambridge, 473-496, 2010.

Gajewski, K., Payette, S., and Ritchie, J. C.: Holocene vegetation history at the boreal-forest-shrub-tundra transition in northwestern Quebec, J. Ecology., 81, 433-443, 1993.

Geirsdóttir, Á., Miller, G. H., Larsen, D. J., and Ólafsdóttir, S.: Abrupt Holocene climate transitions in the northern North Atlantic region recorded by synchronized lacustrine records in Iceland, Quat. Sci. Rev., 70, 48-62, 2013. 
Giraudeau, J., Cremer, M., Manthe, S., Labeyrie, L., and Bond, G.: Coccolith evidence for instabilities in surface circulation south of Iceland during Holocene times, Earth Plan. Sci. Lett., 179, 257268, 2000.

Grace, J., Berninger, F., and Nagy, L.: Impacts of climate change on the tree line, Ann. Bot.-London, 90, 537-544, 2002.

Grimm, E. C., Maher, L. J., Jr., and Nelson, D. M.: The magnitude of error in conventional bulk-sediment radiocarbon dates from central North America, Quat. Res., 72, 301-308, 2009.

Grudd, H., Briffa, K. R., Karlén, W., Bartholin, T. S., Jones, P. D., and Kromer, B.: A 7400-year tree-ring chronology in northern Swedish Lapland: natural climatic variability expressed on annual to millennial timescales, Holocene, 12, 657-665, 2002.

Guiot, J. and de Vernal, A.: Transfer functions: methods for quantitative paleoceanography based on microfossils, In C. HillaireMarcel and A. de Vernal (eds.) Proxies in Late Cenozoic Paleoceanography, Elsevier, 523-563, 2007.

Hald, M., Andersson, C., Ebbesen, H., Jansen, E., KlitgaardKristensen, D., Risebrobakken, B., Salomonsen, G. R., Sarnthein, M., Sejrup, H. P., and Telford, R. J.: Variations in temperature and extent of Atlantic water in the northern North Atlantic during the Holocene, Quat. Sci. Rev., 26, 3423-3440, 2007.

Hammarlund, D., Barnekow, L., Birks, H. J. B., Buckardt, B., and Edwards, T. W. D.: Holocene changes in atmospheric circulation recorded in the oxygen-isotope stratigraphy of lacustrine carbonates from northern Sweden, Holocene, 12, 339-351, 2002.

Hammarlund, D., Björck, S., Buchardt, B., Israelson, C., and Thomsen, C. T.: Rapid hydrological changes during the Holocene revealed by stable isotope records of lacustrine carbonates from Lake Igelsjön, southern Sweden, Quat. Sci. Rev., 22, 353-370, 2003.

Hammarlund, D., Velle, G., Wolfe, B. B., Edwards, T. W. D., Barnekow, L., Bergman, J., Holmgren, S., Lamme, S., Snowball, I., Wohlfarth, B., and Possnert, G.: Palaeolimnological and sedimentary responses to Holocene forest retreat in the Scandes Mountains, west-central Sweden, Holocene, 14, 862-876, 2004.

Harsch, M. A., Hulme, P. E., McGlone, M. S., Duncan, R. P.: Are treelines advancing?, A global meta-analysis of treeline response to climate warming, Ecology Lett., 12, 1040-1049, 2009.

Heikkilä, M. and Seppä, H.: A 11000 year palaeotemperature reconstruction from the southern boreal zone in Finland, Quat. Sci. Rev., 22, 541-554, 2003.

Heikkilä, M., Edwards, T. W. D., Seppä, H., and Sonninen, E.: Sediment isotope tracers from Lake Saarikko, Finland, and implications for Holocene hydroclimatology, Quat. Sci. Rev., 29, 21462160, 2010.

Helama, S., Fauria, M., Mielikäinen, K., Timonen, M., and Eronen, M.: Sub-Milankovitch solar forcing of past climates: mid and late Holocene perspectives, Geol. Soc. Am. Bull., 122, 1981-1988, 2010.

Helama, S., Seppä, H., Bjune, A.E. and Birks, H.J.B.: Fusing pollen-stratigraphic and dendroclimatic proxy data to reconstruct summer temperature variability during the past $7.5 \mathrm{ka}$ in subarctic Fennoscandia, J. Paleolimnol., 48, 272-286, 2012.

Hobbie, J. E.: Polar limnology, Ecos. World, 23, 63-105, 1984.

$\mathrm{Hu}$, F. S., Ito, E., Brubaker, L. B., and Anderson, P. M.: Ostracode geochemical record of Holocene climatic change and implications for vegetational response in the northwestern Alaska Range, Quat. Res., 49, 86-95, 1998.
Husum, K. and Hald, M.: A continuous marine record 80001600 cal. year BP from the Malangenfjord, north Norway: foraminiferal and isotopic evidence, Holocene, 14, 877-887, 2004.

Ilyashuk, E. A., Ilyashuk, B. P., Hammarlund, D., and Larocque, I.: Holocene climatic and environmental changes inferred from midge records (Diptera: Chironomidae, Chaoboridae, Ceratopogonidae) at Lake Berkut, southern Kola Peninsula, Russia, Holocene, 15, 897-914, 2005.

Irvine, F., Cwynar, L. C., Vermaire, J. C., and Rees, A. B. H.: Midge-inferred temperature reconstructions and vegetation change over the last $\sim 15000$ years from Trout Lake, northern Yukon Territory, eastern Beringia, J. Paleolimnol., 48, 133-146, 2012.

Janbu, A. D., Paasche, Ø., and Talbot, M. R.: Paleoclimate changes inferred from stable isotopes and magnetic properties of organicrich lake sediments in Arctic Norway, J. Paleolimnol., 46, 29-44, 2011.

Jansen, E., Andersson, C., Moros, M., Nisancioglu, K. H., Nyland, B. F., Telford, R. J.: The early to mid Holocene thermal optimum in the northern North Atlantic and Nordic Seas: the role of orbital forcing and Holocene century to millennial scale climate events, in: Natural Climate Variability and Global Warming: a Holocene Perspective, edited by: Batterbee, R. W., Binnet, H. A., Blackwell Publishing Ltd., 123-137, 2008.

Jennings, A. E., Weiner, N. J., Helgadóttir, G., and Andrews, J. T.: Modern foraminiferal faunas of the SW to N Iceland shelf: Oceanographic and environmental controls, J. Foramin. Res., 34, 180-207, 2004.

Jennings, A. E., Andrews, J., and Wilson, L.: Holocene environmental evolution of the SE Greenland Shelf North and South of the Denmark Strait: Irminger and East Greenland current interactions, Quat. Sci. Rev., 30, 980-998, 2011.

Jones, P. D., Briffa, K. R., Osborn, T. J., Lough, J. M., van Ommen, T. D., Vinther, B. M., Luterbacher, J., Wahl, E. R., Zwiers, F W., Mann, M. E., Schmidt, G. A., Ammann, C. M., Buckley, B. M., Cobb, K. M., Esper, J., Goosse, H., Graham, N., Jansen, E., Kiefer, T., Kull, C., Küttel, M., Mosley-Thompson, E., Overpeck, J. T., Riedwyl, N., Schulz, M., Tudhope, A. W., Villalba, R., Wanner, H., Wolff, E., and Xoplaki, E.: High-resolution palaeoclimatology of the last millennium: A review of current status and future prospects, Holocene, 19, 3-49, 2009.

Jones, V. J., Leng, M. J., Solovieva, N., Sloane, H. J., and Tarasov, P.: Holocene climate of the Kola Peninsula; evidence from the oxygen isotope record of diatom silica, Isot. Quat. Paleoenviron. Reconstr., 23, 833-839, 2004.

Jones, V. J., Solovieva, N., Self, A. E., McGowan, S., Rosän, P., and Salonen, J. S., Seppä, H., Väliranta, M., Parrott, E., and Brooks, S. J.: The influence of Holocene tree-line advance and retreat on an arctic lake ecosystem: a multi-proxy study from Kharinei Lake, North Eastern European Russia, J. Paleolim., 46, 123-137, 2011.

Jonsson, C. E., Andersson, S., Rosqvist, G. C., and Leng, M. J.: Reconstructing past atmospheric circulation changes using oxygen isotopes in lake sediments from Sweden, Clim. Past, 6, 49-62, doi:10.5194/cp-6-49-2010, 2010.

Juggins, S. and Birks, H. J. B.: Quantitative environmental reconstructions from biological data, in: Tracking Environmental Change Using Lake Sediments, Vol. 5, Data Handling and Nu- 
merical Techniques, edited by: Birks, H. J. B., Lotter, A. F., Juggins, S., and Smol, J. P., Springer, Dordrecht, 431-494, 2012.

Justwan, A., Koç, N., and Jennings, A. E.: Evolution of the Irminger and East Icelandic Current systems through the Holocene, revealed by diatom-based sea surface temperature reconstructions, Quat. Sci. Rev., 27, 1571-1582, 2008.

Kaplan, M. R., Wolfe, A. P., and Miller, G. H.: Holocene environmental variability in southern Greenland inferred from lake sediments, Quat. Res., 58, 149-159, 2002.

Kaufman, D. S.: A new synthesis of Arctic Holocene proxy climate records. Abstract PP31A-1832 presented at 2011 Fall Meeting, AGU, San Francisco, Calif., 5-9 December, 2011.

Kaufman, D. S., Ager, T. A., Anderson, N. J., Anderson, P. M., Andrews, J. T., Bartelein, P. J., Burbaker, L. B., Coats, L. L., Cwynar, L. C., Duval, M. L., Dyke, A. S., Edwards, M. E., Eiser, W. R., Gajewski, K., Geisodottir, A., Hu, F. S., Jennings, A. E., Kaplan, M. R., Kewin, M. W., Lozhkin, A. V., MacDonald, G. M., Miller, G. H., Mock, C. J., Oswald, W. W., Otto-Blisner, B. L., Porinchu, D. F., Rühland, K., Smol, J. P., Steig, E. J., and Wolfe, B. B.: Holocene thermal maximum in the western Arctic (0-180 W), Quat. Sci. Rev., 23, 529-560, 2004.

Kaufman, D. S., Axford, Y., Anderson, R. S., Lamoureux, S. F., Schindler, D. E., Walker, I. R., and Werner, A.: A multi-proxy record of the Last Glacial Maximum and last 14,500 years of paleoenvironmental change at Lone Spruce Pond, southwestern Alaska, J. Paleolimnol., 48, 9-26, 2012.

Kerwin, M. W., Overpeck, J. T., Webb, R. S., and Anderson, K. H.: Pollen-based summer temperature reconstructions for the eastern Canadian boreal forest, subarctic, and Arctic, Quat. Sci. Rev., 23, 1901-1924, 2004.

Kheshgi, H. S. and Lapenis, A. G.: Estimating the accuracy of Russian palaeotemperature reconstructions, Palaeogeogr., Palaeoclim., Palaeoecol., 121, 221-237, 1996.

Klitgaard-Kristensen, D., Sejrup, H. P., and Haflidason, H.: The last 18 kyr fluctuations in Norwegian sea surface conditions and implications for the magnitude of climatic change: Evidence from the North Sea, Paleoceanogr., 16, 455-467, 2001.

Koç, N., Jansen, E., and Haflidason, H. Paleoceanographic reconstructions of surface ocean conditions in the Greenland, Iceland and Norwegian Seas through the last $14 \mathrm{ka}$ based on diatoms, Quat. Sci. Rev., 12, 115-140, 1993.

Koerner, R. M.: Mass balance of glaciers in the Queen Elizabeth Islands, Nunavut, Canada, Ann. Glaciol., 42, 417-423, 2005.

Korhola, A., Weckström, J., Holmström, L., and Erästö, P.: A quantitative Holocene climatic record from diatoms in northern Fennoscandia, Quat. Res., 54, 284-294, 2000.

Korhola, A., Vasko, K., Toivonen, H. T. T., and Olander, H.: Holocene temperature changes in northern Fennoscandia reconstructed from chironomids using Bayesian modelling, Quat. Sci. Rev., 21, 1841-1860, 2002.

Kucera, M.: Chapter six "Planktonic Foraminifera as tracers of past oceanic environments", in: Developments in Marine Geology, Vol. 1, edited by: Hillaire-Marcel, C. and de Vernal, A., Elsevier, 213-262, 2007.

Kucera, M., Weinelt, M., Kiefer, T., Pflaumann, U., Hayes, A., Weinelt, M., Chen, M.-T., Mix, A. C., Barrows, T. T., Cortijo, E., Duprat, J., Juggins, S., and Waelbroeck, C.: Reconstruction of sea-surface temperatures from assemblages of planktonic foraminifera: Multi-technique approach based on geographically constrained calibration datasets and its application to glacial Atlantic and Pacific Oceans, Quat. Sci. Rev., 24, 951-998, 2005.

Kuoppamaa, M., Huusko, A., and Hicks, S.: Pinus and Betula pollen accumulation rates from the northern boreal forest as a record of interannual variation in July temperature, J. Quat. Sci., 24, 513-521, 2009.

Larocque, I. and Bigler, C.: Similarities and discrepancies between chironomid- and diatom-inferred temperature reconstructions through the Holocene at Lake 850, northern Sweden, Quat. Internat., 122, 109-121, 2004.

Larsen, D. J., Miller, G. H., Geirsdóttir, Á., and Ólafsdóttir, S.: Non-linear Holocene climate evolution in the North Atlantic: a high-resolution, multi-proxy record of glacier activity and environmental change from Hvítárvatn, central Iceland, Quat. Sci. Rev., 39, 14-25, 2012.

Lauritzen, S.-E. and Lundberg, J.: Calibration of the speleothem delta function: an absolute temperature record for the Holocene in northern Norway, Holocene, 9, 659-669, 1999.

Ledu, D. Rochon, A., de Vernal, A., and St-Onge, G.: Holocene sea-ice history and climate variability along the main axis of the Northwest Passage, Canadian Arctic, Paleoceanogr., 25, PA2213, doi:10.1029/2009PA001817, 2010.

Leng, M. J. and Marshall, J. D.: Palaeoclimate interpretation of stable isotope data from lake sediment archives, Quat. Sci. Rev., 23, 811-831, 2004.

Levac, E.: High resolution Holocene palynological record from the Scotian Shelf, Mar. Micropaleontol., 43, 179-197, 2001.

Levac, E., de Vernal, A., and Blake, W. Jr.: Holocene paleoceanography of the northernmost Baffin Bay: palynological evidence, J. Quat. Sci., 16, 353-363, 2001.

Levy, L. B., Kaufman, D. S., and Werner, A.: Holocene glacier fluctuations, Waskey Lake, northeastern Ahklun Mountains, southwestern Alaska, Holocene, 14, 185-193, 2004.

Linderholm, H. W., Björklund, J. A., Seftigen, K., Gunnarson, B. E., Grudd, H., Jeong, J.-H., Drobyshev, I., and Liu, Y.: Dendroclimatology in Fennoscandia - from past accomplishments to future potential, Clim. Past, 6, 93-114, doi:10.5194/cp-6-93-2010, 2010.

Linge, H., Lauritzen, S.-E., Andersson, C., Hansen, J. K., Skoglund, R. Ø., and Sundqvist, H. S.: Stable isotope records for the last 10000 years from Okshola cave (Fauske, northern Norway) and regional comparisons, Clim. Past, 5, 667-682, doi:10.5194/cp-5667-2009, 2009.

Ljungqvist, F. C., Krusic, P. J., Brattström, G., and Sundqvist, H. S.: Northern Hemisphere temperature patterns in the last 12 centuries, Clim. Past, 8, 227-249, 2012.

Lloyd, J. M., Kuijpers, A., Long, A., Moros, M., and Park, L. A.: Foraminiferal reconstruction of mid- to late-Holocene ocean circulation and climate variability in Disko Bugt, West Greenland, Holocene, 17, 1079-1091, 2007.

MacDonald, G. M.: Postglacial vegetation history of the Mackenzie River Basin, Quat. Res., 28, 245-262, 1987.

MacDonald, G. M., Edwards, T. W. D., Moser, K. A., Pienitz, R., and Smol, J. P.: Rapid response of treeline vegetation and lakes to past climate warming, Nature, 361, 243-246, 1993.

MacDonald, G. M., Porinchu, D. F., Rolland, N., Krementsky, K. V. and Kaufman, D. S.: Paleolimnological evidence of the response of the central Canadian treeline zone to radiative forc- 
ing and hemispheric patterns of temperature change over the past 2000 years, J. Paleolimnol., 41, 129-141, 2009.

Mann, D. H., Heiser, P. A., and Finney, B. P.: Holocene history of the Great Kobuk sand dunes, northwestern Alaska, Quat. Sci. Rev., 21, 709-731, 2002.

Marchal, O., Cacho, I., Stocker, T. F., Grimalt, J. O., Calvo, E., Martrat, B., Shackleton, N., Vautravers, M., Cortijo, E., van Kreveld, S., Andersson, C., Koç, N., Chapman, M., Sbaffi, L., Duplessy, J.-C., Sarnthein, M., Turon, J.-L., Duprat, J., and Jansen, E.: Apparent long-term cooling of the sea surface in the northeast Atlantic and Mediterranean during the Holocene, Quat. Sci. Rev., 21, 455-483, 2002.

Marcott, S. A., Shakun, J. D., Clark, P. U., and Mix, A. C.: A reconstruction of regional and global temperature for the past 11300 years, Science, 339, 1198-1201, 2013.

Massa, C., Perren, B. B., Gauthier, E., Bichet, V., Petit, C., and Richard, H.: A multiproxy evaluation of Holocene environmental change from Lake Igaliku, South Greenland, J. Paleolimnol., 4, 241-258, 2012.

McDermot, F. M.: Palaeo-climate reconstruction from stable isotope variations in speleothems: a review, Quat. Sci. Rev., 23, 901-918, 2004.

McDermot, F. M., Atkinson, T. C., Fairchild, I. J., Baldini, L. M., and Mattey, D. P.: A first evaluation of the spatial gradients in $\delta^{18} \mathrm{O}$ recorded by European Holocene speleothems, Global Planet. Change, 79, 275-287, 2010.

McKay, J. L., de Vernal, A., Hillaire-Marcel, C., Not, C., Polyak, L., and Darby, D.: Holocene fluctuations in Arctic sea-ice cover: Dinocyst-based reconstructions for the eastern Chukchi Sea, Can. J. Earth Sci., 45, 1377-1397, 2008.

McKay, N. and Kaufman, D.: Holocene climate and glacier variability at Hallet and Greyling Lakes, Chugach Mountains, southcentral Alaska, J. Paleolimnol., 41, 143-159, 2009.

McKay, N., Ault, T. R., and St. George, S.: Improving access to the global paleoclimate dataset through the development of a virtual paleoclimate laboratory in R (vplR), 2nd International Climate Informatics Workshop, Boulder, Colorado, 2012.

Michelutti, N., Wolfe, A. P., Vinebrooke, R. D., Rivard, B., and Briner, J. B.: Recent primary production increases in arctic lakes, Geophys. Res. Lett., 32, L199715, doi:10.1029/2005GL023693, 2005.

Michelutti, N., Blais, J. M., Cumming, B. F., Paterson, A. M., Rühland, K., Wolfe, A. P., and Smol, J. P.: Do spectrally inferred determinations of chlorophyll $a$ reflect trends in lake trophic status?, J. Paleolimnol., 43, 205-217, 2010.

Miller, G. H., Wolfe, A. P., Briner, J. P., Sauer, P. E., and Nesje, A.: Holocene glaciation and climate evolution of Baffin Island, Arctic Canada, Quat. Sci. Rev., 24, 1703-1721, 2005.

Müller, J., Werner, K., Stein, R., Fahl, K., Moros, M., and Jansen, E.: Holocene cooling culminates in sea ice oscillations in Fram Strait, Quat. Sci. Rev., 47, 1-14, 2012.

Nesje, A. and Matthews, J. A.: The Briksdalsbre Event: A winter precipitation-induced decadal-scale glacial advance in southern Norway in the ad 1990s and its implications, Holocene, 22, 249261, 2012.

Nesje, A., Matthews, J. A., Dahl, S. O., Berrisford, M. S., and Andersson, C.: Holocene glacier fluctuations of Flatebreen and winter-precipitation changes in the Jostedalsbreen region, western Norvay, based on glaciolacustrine sediment records, Holocene, 11, 267-280, 2001.

North Greenland Ice-Core Project (NorthGRIP) Members,: High resolution climate record of the Northern Hemisphere reaching into the last Glacial Interglacial Period, Nature, 431, 147-151, 2004.

Ojala, A. E. K., Alenius, T., Seppä, H., and Giesecke, T.: Integrated varve and pollen-based temperature reconstruction from Finland: evidence for Holocene seasonal temperature patterns at high latitudes, Holocene, 18, 529-538, 2008.

Ólafsdóttir, S., Jennings, A. E., Geirsdóttir, Á., Andrews, J., and Miller, G. H.: Holocene variability of the North Atlantic Irminger current on the south- and northwest shelf of Iceland, Mar. Micropaleontol., 77, 101-118, 2010.

Olsen, J., Björck, S., Leng, M. J., Gudmundsdottir, E. R., Odgaard, B. V., Lutz, C. M., Kendrick, C. P., Andersen, T. J., and Seidenkrantz, M.-S.: Lacustrine evidence of Holocene environmental change from three Faroese lakes: a multproxy XRF and stable isotope study, Quat. Sci. Rev., 29, 2764-2780, 2010.

Overpeck, J. T., Meehl, G. A., Bondy, S., and Easterling, D. R.: Climate data challenges in the 21st centry, Science, 331, 700702, 2011.

Peros, M. C. and Gajewski, K.: Holocene climate and vegetation change on Victoria Island, western Canadian Arctic, Quat. Sci. Rev., 27, 235-249, 2008.

Peros, M., Gajewski, K., Paull, T., Ravindra, R., and Podritske, B.: Multi-proxy record of postglacial environmental change, southcentral Melville Island, Northwest Territories, Canada, Quat. Res., 73, 247-258, 2010.

Perren, B., Anderson, N. J., Douglas, M. V., and Fritz, S.: The influence of temperature, moisture, and eolian activity on Holocene lake development in West Greenland, J. Paleolimnol., 48, 223239, 2012.

Pienitz, R., Smol, J. P., and MacDonald, G. M.: Paleolimnological reconstruction of Holocene climatic trends from two boreal treeline lakes, Northwest Territories, Canada, Arct. Antarct. Alp. Res., 31, 82-93, 1999.

Risebrobakken, B., Jansen, E., Andersson, C., Mjelde, E., and Hevrøy, K.: A high-resolution study of Holocene paleoclimatic and paleoceanographic changes in the Nordic Seas, Paleoceanogr., 18, 1017, doi:10.1029/2002PA000764, 2003.

Rosell-Melé, A. and McClymont, E.: Chapter eleven - Biomarkers as paleoceanographic proxies, in: Developments in Marine Geology, Vol. 1, edited by: Hillaire-Marcel, C. and de Vernal, A.,Elsevier, 441-490, 2007.

Rosén, P., Segerström, U., Eriksson, L., Renberg, I., and Birks, H. J. B.: Holocene climatic change reconstructed from diatoms, chironomids, pollen and near-infrared spectroscopy at an alpine lake (Sjuodjijaure) in northern Sweden, Holocene, 11, 551-562, 2001.

Rosenthal, Y.: Chapter nineteen - Elemental proxies for reconstructing Cenozoic seawater paleotemperatures from calcareous fossils, in: Developments in Marine Geology, Vol. 1, edited by: Hillaire-Marcel, C. and de Vernal, A., Elsevier, 765-797, 2007.

Rouillard, A., Rosén, P., Douglas, M. S. V., Pienitz, R., and Smol, J. P.: A model for inferring lakewater dissolved organic carbon (DOC) in lakewater from visible-near-infrared spectroscopy (VNIRS) measures in lake sediment, J. Paleolimnol., 46, 187202, 2011. 
Rouillard, A., Michelutti, N., Douglas, M. S. V., and Smol, J. P.: Using paleolimnology to track Holocene climate fluctuations and aquatic ontogeny in poorly buffered High Arctic lakes, Palaeogeogr., Palaeoclim., Palaeoecol., 321/322, 1-15, 2012.

Rühland, K., Paterson, A. M., and Smol, J. P.: Hemispheric-scale patterns of climate-related shifts in planktonic diatoms from North American and European lakes, Global Change Biol., 14, 2740-2754, 2008.

Sachse D., Billault I., and Bowen, G. J.: Molecular paleohydrology: Interpreting the hydrogen-isotopic composition of lipid biomarkers from photosynthesizing organisms, Ann. Rev. Earth Pl. Sc., 40, 221-249, 2012.

Sagarin, R. and Micheli, F.: Climate change in nontraditional data sets, Science, 26, 811-811, 2001.

Salonen, J. S., Seppä, H., Väliranta, M., Jones, V. J., Self, A., Heikkilä, M., Kultti, S., and Yang, H.: The Holocene thermal maximum and late-Holocene cooling in the tundra of $\mathrm{NE} \mathrm{Eu-}$ ropean Russia, Quat. Res., 75, 501-511, 2011.

Sarmaja-Korjonen, K. and Seppä, H.: Abrupt and consistent responses of aquatic and terrestrial ecosystems to the $8200 \mathrm{cal}$. year cold event: a lacustrine record from Lake Arapisto, Finland, Holocene, 17, 457-467, 2007.

Sarnthein, M., Van Kreveld, S., Erlenkeuser, H., Grootes, P. M., Kucera, M., Pflaumann, U., and Schulz, M.: Centennial-tomillennial-scale periodicities of Holocene climate and sediment injections off the western Barents shelf, $75^{\circ} \mathrm{N}$, Boreas, 32, 447461, 2003.

Sawada, M., Gajewski, K., de Vernal, A., and Richard, P.: Comparison of marine and terrestrial Holocene climate reconstructions from northeastern North America, Holocene, 9, 267-277, 1999.

Schiff, C. J., Kaufman, D. S., Wolfe, A., Dodd, J., and Sharp, Z.: Late Holocene storm-trajectory changes inferred from the oxygen isotope composition of lake diatoms, south Alaska, J. Paleolimnol., 41, 189-208, 2009.

Schmidt, S., Wagner, B., Heiri, O., Klug, M., Bennike, O. L. E., and Melles, M.: Chironomids as indicators of the Holocene climatic and environmental history of two lakes in Northeast Greenland, Boreas, 40, 116-130, 2011.

Seidenkrantz, M.-S.: Benthic foraminifera as palaeo sea-ice indicators in the subarctic realm examples from the Labrador SeaBaffin Bay region, Quat. Sci. Rev., 79, 135-144, 2013.

Sejrup, H. P., Birks, H. J. B., Klitgaard-Kristensen, D., and Madsen, H.: Benthonic foraminiferal distributions and quantitative transfer functions for the northwest European continental margin, Mar. Micropaleontol., 53, 197-226, 2004a.

Sejrup, H. P., Haflidason, H., Hjelstuen, B. O., Nygård, A., Bryn, P., and Lien, R.: Pleistocene development of the SE Nordic Seas margin, Mar. Geol., 213, 169-200, 2004b.

Sejrup, H. P., Haflidason, H., and Andrews, J. T.: A Holocene North Atlantic SST record and regional climate variability, Quat. Sci. Rev., 30, 3181-3195, 2011.

Seppä, H. and Birks, H. J. B.: July mean temperature and annual precipitation trends during the Holocene in the Fennoscandian tree-line area: pollen-based climate reconstructions, Holocene, 11, 527-539, 2001.

Seppä, H. and Birks, H. J. B.: Holocene climate reconstructions from the Fennoscandian tree-line area based on pollen data from Toskaljävri, Quat. Res., 57, 191-199, 2002.
Seppä, H. and Poska, A.: Holocene annual mean temperature changes in Estonia and their relationship to solar insolation and atmospheric circulation patterns, Quat. Res., 61, 22-31, 2004.

Seppä, H., Nyman, M., Korhola, A., and Weckström, J.: Changes of treelines and alpine vegetation in relation to post-glacial climate dynamics in northern Fennoscandia based on pollen and chironomid records, J. Quat. Sci., 17, 287-301, 2002.

Seppä, H., Hammarlund, D., and Antonsson, K.: Low-frequency and high-frequency changes in temperature and effective humidity during the Holocene in south-central Sweden: implications for atmospheric and oceanic forcings of climate, Clim. Dynam., 25, 285-297, 2005.

Seppä, H., MacDonald, G. M., Birks, H. J. B., Gervais, B. R., and Snyder, J. A.: Late-Quaternary summer temperature changes in the northern-European tree-line region, Quat. Res., 69, 404-412, 2008.

Seppä, H., Bjune, A. E., Telford, R. J., Birks, H. J. B., and Veski, S.: Last nine-thousand years of temperature variability in Northern Europe, Clim. Past, 5, 523-535, doi:10.5194/cp-5-523-2009, 2009.

Shemesh, A., Rosqvist, G., Rietti-Shati, M., Rubensdotter, L., Bigler, C., Yam, R., and Karlén, W.: Holocene climatic change in Swedish Lapland inferred from an oxygen-isotope record of lacustrine biogenic silica, Holocene, 11, 447-454, 2001.

Smith, L. M., Andrews, J. T., Castañeda, I. S., Kristjánsdóttir, G. B., Jennings, A. E., and Sveinbjörnsdóttir, Á. E.: Temperature reconstructions for SW and N Iceland waters over the last $10 \mathrm{cal} \mathrm{ka}$ based on $\delta^{18} \mathrm{O}$ records from planktic and benthic Foraminifera, Quat. Sci. Rev., 24, 1723-1740, 2005.

Smol, J. P.: Paleoclimate proxy data from freshwater arctic diatoms, Verh. Internat. Verin. Limnol., 23, 837-844, 1988.

Smol, J. P. and Douglas, M. S. V.: From controversy to consensus: making the case for recent climatic change in the Arctic using lake sediments, Front. Ecol. Environ., 5, 466-474, 2007.

Smol, J. P., Wolfe, A. P., Birks, H. J. B., Douglas, M. S. V., Jones, V. J., Korhola, A., Pienitz, R., Rühland, K., Sanna Sorvari, S., Antoniades, D., Brooks, S. J., Fallu, M. A., Hughes, M., Keatley, B. E., Laing, T. E., Michelutti, N., Nazarova, L., Nyman, M., Paterson, A. M., Perren, B., Quinlan, R., Rautio, M., Saulnier-Talbot, E., Siitonen, S., Solovieva, N., and Weckström, J.: Climatedriven regime shifts in the biological communities of arctic lakes, P. Natl. Acad. Sci. USA, 102, 4397-4402, 2005.

Solignac, S., Giraudeau, J., and de Vernal, A.: Holocene sea surface conditions in the western North Atlantic: spatial and temporal heterogeneities, Paleoceanogr., 21, PA2004, doi:10.1029/2005PA001175, 2006.

Solovieva, N., Tarasov, P. E., and MacDonald, G.: Quantitative reconstruction of Holocene climate from the Chuna Lake pollen record, Kola Peninsula, northwest Russia, Holocene, 15, 141148, 2005.

St. Amour, N. A., Hammarlund, D. A. N., Edwards, T. W. D., and Wolfe, B. B.: New insights into Holocene atmospheric circulation dynamics in central Scandinavia inferred from oxygenisotope records of lake-sediment cellulose, Boreas, 39, 770-782, 2010.

Sundqvist, H. S., Zhang, Q., Moberg, A., Holmgren, K., Körnich, H., Nilsson, J., and Brattström, G.: Climate change between the mid and late Holocene in northern high latitudes - Part 1: Survey 
of temperature and precipitation proxy data, Clim. Past, 6, 591608, doi:10.5194/cp-6-591-2010, 2010.

Sundqvist, H. S., Kaufman, D. S., McKay, N. P., Balascio, N. L., Briner, J. P., Cwynar, L. C., Sejrup, H. P., Seppä, H., Subetto, D. A., Andrews, J. T., Axford, Y., Bakke, J., Birks, H. J. B., Brooks, S. J., de Vernal, A., Jennings, A. E., Ljungqvist, F. C., Rühland, K. M., Saenger, C., Smol, J. P., and Viau, A. E.: Arctic Holocene proxy climate database - new approaches to assessing geochronological accuracy and encoding climate variables, Clim. Past Discuss., 10, 1-63, doi:10.5194/cpd-10-1-2014, 2014.

Szeicz, J. M., MacDonald, G. M., and Duk-Rodkin, A.: Late Quatarny vegetation history of the central Mackenzie Mountains, Northwest Territories, Canada, Palaeogeog., Palaeoclim., Palaeoecol., 113, 351-371, 1995.

Thomas, E. K., Szymanski, J., and Briner, J. P.: Holocene alpine glaciation inferred from lacustrine sediments on northeastern Baffin Island, Arctic Canada, J. Quat. Sci., 25, 146-161, 2010.

Thornalley, D. J. R., Elderfield, H., and McCave, I. N.: Holocene oscillations in temperature and salinity of the surface subpolar North Atlantic, Nature, 457, 711-714, 2009.

Tillman, P. K., Holzkämper, S., Kuhry, P., Sannel, A. B. K., Loader, N. J., and Robertson, I.: Long-term climate variability in continental subarctic Canada: A 6200-year record derived from stable isotopes in peat, Palaeogeog., Palaeoclim., Palaeoecol., 298, 235-246, 2010.

Tingley, M. P., Craigmile, P.F., Haran, M., Li, B., Mannshardt, E., and Rajaratnam, B.: Piecing together the past: statistical insights into paleoclimatic reconstructions, Quat. Sci. Rev., 35, 1-22, 2012.

Vare, L. L., Massé, G., Gregory, T. R., Smart, C. W., and Belt, S. T.: Sea ice variations in the central Canadian Arctic Archipelago during the Holocene, Quat. Sci. Rev., 28, 1354-1366, 2009.

Vasskog, K., Paasche, Ø., Nesje, A., Boyle, J. F., and Birks, H. J. B.: A new approach for reconstructing glacier variability based on lake sediments recording input from more than one glacier, Quat. Res., 77, 192-204, 2012.

Velle, G., Brooks, S. J., Birks, H. J. B., and Willassen, E.: Chironomids as a tool for inferring Holocene climate: an assessment based on six sites in southern Scandinavia, Quat. Sci. Rev., 24, 1429-1462, 2005.

Viau, A. E. and Gajewski, K.: Reconstructing millennial-scale, regional paleoclimates of boreal Canada during the Holocene, J. Climate., 22, 316-330, 2009.

Vinther, B. M., Andersen, K. K., Jones, P. D., Briffa, K. R., and Cappelen, J.: Extending Greenland temperature records into the late eighteenth century, J. Geophys. Res., 111, D11105, doi:10.1029/2005JD006810, 2006.

Vinther, B. M., Clausen, H. B., Fisher, D. A., Koerner, R. M., Johnsen, S. J., Andersen, K. K., Dahl-Jensen, D., Rasmussen, S. O., Steffensen, J. P., and Svensson, A. M.: Synchronizing ice cores from the Renland and Agassiz ice caps to the Greenland ice core chronology, J. Geophys. Res., 113, D08115, doi:10.1029/2007JD009143, 2008.
Vinther, B. M., Buchardt, S. L., Clausen, H. B., Dahl-Jensen, D., Johnsen, S. J., Fisher, D. A., Koerner, R. M., Raynaud, D., Lipenkov, V., Andersen, K. K., Blunier, T., Rasmussen, S. O., Steffensen, J. P., and Svensson, A. M.: Holocene thinning of the Greenland ice sheet, Nature, 461, 385-388, 2009.

Vinther, B. M., Dahl-Jensen, D., Johnsen, S. J., Jones, P., Briffa, K. R., Clausen, H. B., and Andersen, K. K.: Climatic signals in multiple highly resolved stable isotope records from Greenland, Quat. Sci. Rev., 29, 522-538, 2010.

von Storch, H. , Zorita, E., Jones, J. M., Dimitriev, Y., GonzálezRouco, F., and Tett, S. F. B.: Reconstructing past climate from noisy data, Science, 306, 679-682, 2004.

Voronina, E., Polyak, L., de Vernal, A., and Peyron, O.: Holocene variations of sea-surface conditions in the southeastern Barents Sea, reconstructed from dinoflagellate cyst assemblages, J. Quat. Sci., 16, 717-727, 2001.

Vorren, K.-D., Blaauw, M., Wastegård, S., Plicht, J. V. D., and Jensen, C.: High-resolution stratigraphy of the northernmost concentric raised bog in Europe: Sellevollmyra, Andøya, northern Norway, Boreas, 36, 253-277, 2007.

Vorren, K.-D., Jensen, C. E., and Nilssen, E.: Climate changes during the last ca. 7500 years as recorded by the degree of peat humification in the Lofoten region, Norway, Boreas, 41, 13-30, 2012.

Walker, I. R.: Midges: Chironomidae and related Diptera, in: Tracking Environmental Change Using Lake Sediments, Vol. 4, Zoological Indicators, edited by: Smol, J. P., Birks, H. J. B. and Last, W. M., Kluwer Academic Publishers, Dordrecht, 43-66, 2001.

Willemse, N. W. and Törnqvist, T. E.: Holocene century-scale temperature variability from West Greenland lake records, Geology, 27, 580-584, 1999.

Wolfe, B. B., Edwards, T. W. D., Aravena, R., and MacDonald, G. M.: Rapid Holocene hydrologic change along boreal treeline revealed by $\delta^{13} \mathrm{C}$ and $\delta^{18} \mathrm{O}$ in organic lake sediments, Northwest Territories, Canada, J. Paleolimnol., 15, 171-181, 1996.

Wolfe, B. B., Edwards, T. W. D., Aravena, R., Forman, S L., Warner, B. G., Velichko, A. A., and MacDonald, G. M.: Holocene paleohydrology and paleoclimate at treeline, northcentral Russia, inferred from oxygen isotope records in lake sediment cellulose, Quat. Res., 53, 319-329, 2000.

Wolfe, A. P., Miller, G. H., Olsen, C. A., Forman, S. L., Doran, P. T., and Holmgren, S. U.: Geochronology of high latitude lake sediments, in: Long-term Environmental Change in Arctic and Antarctic Lakes, edited by: Pienitz, R. M. S., Douglas, V., Smol, J. P., 19-52, 2004.

Wooller, M. J., Kurek, J., Gaglioti, B. V., Cwynar, L. C., Bigelow, N., Reuther, J. D., Gelvin-Reymiller, C., and Smol, J. P.: An $\sim 1200$ year paleolimnological perspective for emerging archaeological findings at Quartz Lake, Alaska, J. Paleolimnol., 48, 8399, 2012.

Zabenskie, S. and Gajewski, K.: Post-glacial climatic change on Boothia Peninsula, Nunavut, Canada, Quat. Res. 68, 261-270, 2007. 